Prepared in cooperation with the Bureau of Indian Affairs and the Arizona Department of Water Resources

\title{
Ground-Water, Surface-Water, and Water-Chemistry Data, Black Mesa Area, Northeastern Arizona-2006-07
}

Open-File Report 2008-1324 
This page left intentionally blank. 


\section{Ground-Water, Surface-Water, and Water-Chemistry Data, Black Mesa Area, Northeastern Arizona-2006-07}

By Margot Truini and J.P. Macy

Prepared in cooperation with Bureau of Indian Affairs and the

Arizona Department of Water Resources

Open-File Report 2008-1324 


\section{U.S. Department of the Interior DIRK KEMPTHORNE, Secretary}

\section{U.S. Geological Survey \\ Mark D. Myers, Director}

U.S. Geological Survey, Reston, Virginia: 2008

This report and any updates to it are available online at:

http://pubs.usgs.gov/of/2008/1324

For product and ordering information:

World Wide Web: http://www.usgs.gov/pubprod

Telephone: 1-888-ASK-USGS

For more information on the USGS - the Federal source for science about the Earth, its natural and living resources, natural hazards, and the environment:

World Wide Web: http://www.usgs.gov

Telephone: 1-888-ASK-USGS

Any use of trade, product, or firm names is for descriptive purposes only and does not imply endorsement by the U.S. Government.

Although this report is in the public domain, permission must be secured from the individual copyright owners to reproduce any copyrighted materials contained within this report.

Suggested citation:

Truini, Margot, and Macy, J.P., 2008, Ground-water, surface-water, and water-chemistry data, Black Mesa area, northeastern Arizona, 2006-07: U.S. Geological Survey Open-File Report 2008-1324, 33 p.

Produced in the Western Region, Menlo Park, California Manuscript approved for publication, October 10, 2008

Text edited by Tracey Suzuki

Layout by David R. Jones

FRONT COVER—Photograph of Black Mesa observation well number 1. Photo taken by Margot Truini. 


\section{Contents}

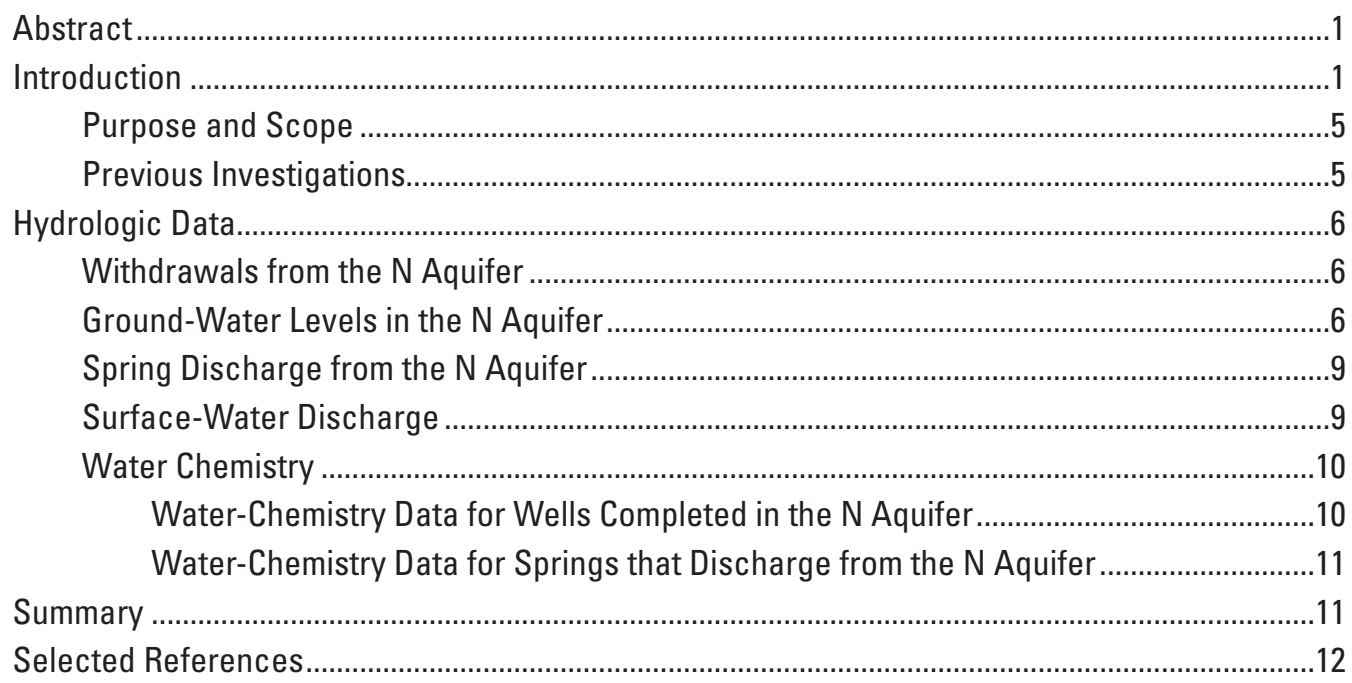

\section{Figures}

1. Location of water monitoring program study area, Black Mesa, northeastern Arizona.............2

2. Rock formation and hydrogeologic units of the Black Mesa area, northeastern Arizona...........3

3. Water-level changes in N aquifer wells from the prestress period (prior to 1965),

Black Mesa area, northeastern Arizona ...............................................................................

4. Observed water levels (1950-2007) in annual observation-well network, $\mathrm{N}$ aquifer, Black Mesa area, northeastern Arizona................................................................ 16

5. Observed water levels changes in continuous-record observation, wells, BM1-BM6, 1963-2007, N aquifer, Black Mesa area, northeastern Arizona. .................................................20

6. Surface-water and water-chemistry data-collection sites, $\mathrm{N}$ aquifer, Black Mesa area, northeastern Arizona, 2006-07.............................................................. 21

7. Discharge from Moenkopi School Spring, N aquifer, northeastern Black Mesa area, northeastern Arizona, 1987-2007.

8. Streamflow characteristics at Moenkopi Wash at Moenkopi (09401260), Pasture Canyon Springs near Tuba City (09401265), Dinnebito Wash near Sand Spring (09401110), and Polacca Wash near Second Mesa (09400568), and annual precipitation at Betatakin, Arizona, Black Mesa area, northeastern Arizona.

9. Median discharge for November, December, January, and February for water years 1977-2006 for Moenkopi Wash at (A) Moenkopi (09401260), (B) Dinnebito Wash near Sand Springs (09401110), and (C) Polacca Wash near Second Mesa (09400568), Black Mesa area, northeastern Arizona

10. Water chemistry and distribution of dissolved solids in the N aquifer, Black Mesa area, northeastern Arizona, 2007.

11. Dissolved-solids concentrations with linear trend line for water samples from industrial well Peabody 5, N aquifer, Black Mesa area, northeastern Arizona, 1980-2007

12. Concentrations of dissolved solids, chloride, and sulfate for water samples from Moenkopi School Spring, N aquifer, Black Mesa area, northeastern Arizona, 1984-2007 


\section{Tables}

1. Identification numbers and names of monitoring program study wells, 2006-07, Black Mesa area, northeastern Arizona

2. Water-level changes in monitoring program wells completed in the $\mathrm{N}$ aquifer, Black Mesa area, northeastern Arizona, prestress period (prior to 1965) to 2007.

3. Well-construction characteristics, depth to top of $\mathrm{N}$ aquifer, and type of data collected for wells in monitoring program, Black Mesa area, northeastern Arizona, 2006-07..

4. Median changes in water levels in monitoring program wells, 2006-07 and prestress period (prior to 1965) to 2007, N aquifer, Black Mesa area, northeastern Arizona .

5. Discharge measurements for Moenkopi School Spring, Black Mesa area, northeastern Arizona, 1952-2007

6. Discharge data, Moenkopi Wash at Moenkopi, Arizona (09401260), calendar year 2006 ........28

7. Discharge data, Dinnebito Wash near Sand Springs, Arizona (09401110), calendar year 2006 .....29

8. Discharge data, Polacca Wash near Second Mesa, Arizona (09400568), calendar year 2006 ......30

9. Discharge data, Pasture Canyon Springs near Tuba City, Arizona (09401265), calendar year 2006

10. Date that monitoring program data collection began and drainage areas for streamflow-gaging stations, Black Mesa area, northeastern Arizona

11. Physical properties and chemical analyses of water from industrial well Peabody 5 completed in the $\mathrm{N}$ and $\mathrm{D}$ aquifers, Black Mesa area, northeastern Arizona, 2007.

12. Specific conductance and concentrations of selected chemical constituents in water from industrial well Peabody 5 completed in the $\mathrm{N}$ and $\mathrm{D}$ aquifers,

Black Mesa area, northeastern Arizona, 1974-2007

13. Physical properties and chemical analyses of $\mathrm{N}$-aquifer water samples from Moenkopi School Spring, Black Mesa area, northeastern Arizona, 2007.

14. Specific conductance and concentrations of selected chemical constituents in $\mathrm{N}$-aquifer water samples from Moenkopi School Spring, Black Mesa area, northeastern Arizona, 1948-2007.

\section{Conversion Factors}

\begin{tabular}{lll}
\hline \multicolumn{1}{c}{ Multiply } & \multicolumn{1}{c}{ By } & \multicolumn{1}{c}{ To obtain } \\
\hline inch (in.) & \multicolumn{1}{c}{ Length } \\
inch (in.) & 2.54 & centimeter $(\mathrm{cm})$ \\
foot (ft) & 25.4 & millimeter $(\mathrm{mm})$ \\
mile (mi) & 0.3048 & meter $(\mathrm{m})$ \\
& 1.609 & kilometer $(\mathrm{km})$ \\
\hline square mile (mi2) & \multicolumn{1}{c}{ Area } & \\
Volume & 2.590 & square kilometer $(\mathrm{km} 2)$ \\
acre-foot (acre-ft) & \multicolumn{1}{c}{ Flow rate } & \\
\hline & 0.001233 & cubic hectometer $(\mathrm{hm} 3)$ \\
\hline cubic foot per second (ft3/s) & 0.02832 & cubic meter per second $(\mathrm{m} 3 / \mathrm{s})$ \\
gallon per minute (gal/min) & 0.06309 & liter per second $(\mathrm{L} / \mathrm{s})$ \\
\hline
\end{tabular}

Temperature in degrees Celsius $\left({ }^{\circ} \mathrm{C}\right)$ may be converted to degrees Fahrenheit $\left({ }^{\circ} \mathrm{F}\right)$ as follows: ${ }^{\circ} \mathrm{F}=\left(1.8 x^{\circ} \mathrm{C}\right)+32$ Vertical coordinate information is referenced to the National Geodetic Vertical Datum of 1929 (NGVD 29). Horizontal coordinate information is referenced to the North American Datum of 1927 (NAD 27). Altitude, as used in this report, refers to distance above the vertical datum. Specific conductance is given in microsiemens per centimeter at 25 degrees Celsius $\left(\mu \mathrm{S} / \mathrm{cm}\right.$ at $\left.25^{\circ} \mathrm{C}\right)$. Concentrations of chemical constituents in water are given either in milligrams per liter $(\mathrm{mg} / \mathrm{L})$ or micrograms per liter $(\mu \mathrm{g} / \mathrm{L})$. 


\title{
Ground-Water, Surface-Water, and Water-Chemistry Data, Black Mesa Area, Northeastern Arizona-2006-07
}

\author{
By Margot Truini and J.P. Macy
}

\section{Abstract}

The $\mathrm{N}$ aquifer is the major source of water in the 5,400 square-mile Black Mesa area in northeastern Arizona. Availability of water is an important issue in northeastern Arizona because of continued water requirements for industrial and municipal use and the needs of a growing population. Precipitation in the Black Mesa area is typically about 6 to 14 inches per year.

The water-monitoring program in the Black Mesa area began in 1971 and is designed to provide information about the long-term effects of ground-water withdrawals from the $\mathrm{N}$ aquifer for industrial and municipal uses. This report presents results of data collected for the monitoring program in the Black Mesa area from January 2006 to September 2007. The monitoring program includes measurements of (1) ground-water withdrawals, (2) ground-water levels, (3) spring discharge, (4) surface-water discharge, and (5) ground-water chemistry. Periodic testing of ground-water withdrawal meters is completed every 4 to 5 years.

The Navajo Tribal Utility Authority (NTUA) yearly totals for the ground-water metered withdrawal data were unavailable in 2006 due to an up-grade within the NTUA computer network. Because NTUA data is often combined with Bureau of Indian Affairs data for the total withdrawals in a well system, withdrawals will not be published in this year's annual report.

From 2006 to 2007, annually measured water levels in the Black Mesa area declined in 3 of 11 wells measured in the unconfined areas of the $\mathrm{N}$ aquifer, and the median change was 0.0 feet. Measurements indicated that water levels declined in 8 of 17 wells measured in the confined area of the aquifer. The median change for the confined area of the aquifer was 0.2 feet. From the prestress period (prior to 1965) to 2007, the median water-level change for 30 wells was -11.1 feet. Median water-level changes were 2.9 feet for 11 wells measured in the unconfined areas and -40.2 feet for 19 wells measured in the confined area.

Spring flow was measured once in 2006 and once in 2007 at Moenkopi School Spring. Flow decreased by 18.9 percent at Moenkopi School Spring. During the period of record, flow fluctuated, and a decreasing trend was apparent.

Continuous records of surface-water discharge in the Black Mesa area have been collected from streamflow gages at the fol- lowing sites: Moenkopi Wash at Moenkopi (1976 to 2006), Dinnebito Wash near Sand Springs (1993 to 2006), Polacca Wash near Second Mesa (1994 to 2006), and Pasture Canyon Springs (August 2004 to December 2006). Median flows during November, December, January, and February of each water year were used as an index of the amount of ground-water discharge to the above named sites. For the period of record at each streamflowgaging station, the median winter flows have generally remained even, showing neither a significant increase nor decrease in flows. There is not a long enough period of record for Pasture Canyon Spring for a trend to be apparent.

In 2007, water samples were collected from 1 well and 1 spring in the Black Mesa area and were analyzed for selected chemical constituents. Concentrations of dissolved solids, chloride, and sulfate have varied at Peabody well 5 for the period of record, and there is an apparent increasing trend. Dissolved-solids, chloride, and sulfate concentrations increased at Moenkopi School Spring during the more than 12 years of record.

\section{Introduction}

The Black Mesa study area in northeastern Arizona includes of about 5,400 $\mathrm{mi}^{2}$ in northeastern Arizona (fig. 1) and has a diverse topography that includes flat plains, mesas, and incised drainages. Black Mesa covers about 2,000 $\mathrm{mi}^{2}$; it has 2,000-foot-high cliffs on its northern and northeastern sides, but slopes gradually down to the south and southwest. Availability of water is an important issue in the study area because of continued ground-water withdrawals, a growing population, and precipitation rates that average about 6 to $14 \mathrm{in} / \mathrm{yr}$ (U.S. Department of Agriculture, 1999). The $\mathrm{N}$ aquifer is the major source of water for industrial and municipal uses in the Black Mesa area, and it comprises three hydraulically connected formations - the Navajo Sandstone, the Kayenta Formation, and the Lukachukai Member of the Wingate Sandstone-that function as a single aquifer (fig. 2).

The $\mathrm{N}$ aquifer is confined under most of Black Mesa, and the overlying stratigraphy prevents recharge to this part of the aquifer (fig. 2). The $\mathrm{N}$ aquifer is unconfined in areas around Black Mesa, and most recharge occurs where the Navajo Sandstone is exposed in the area near Shonto (fig. 3). 


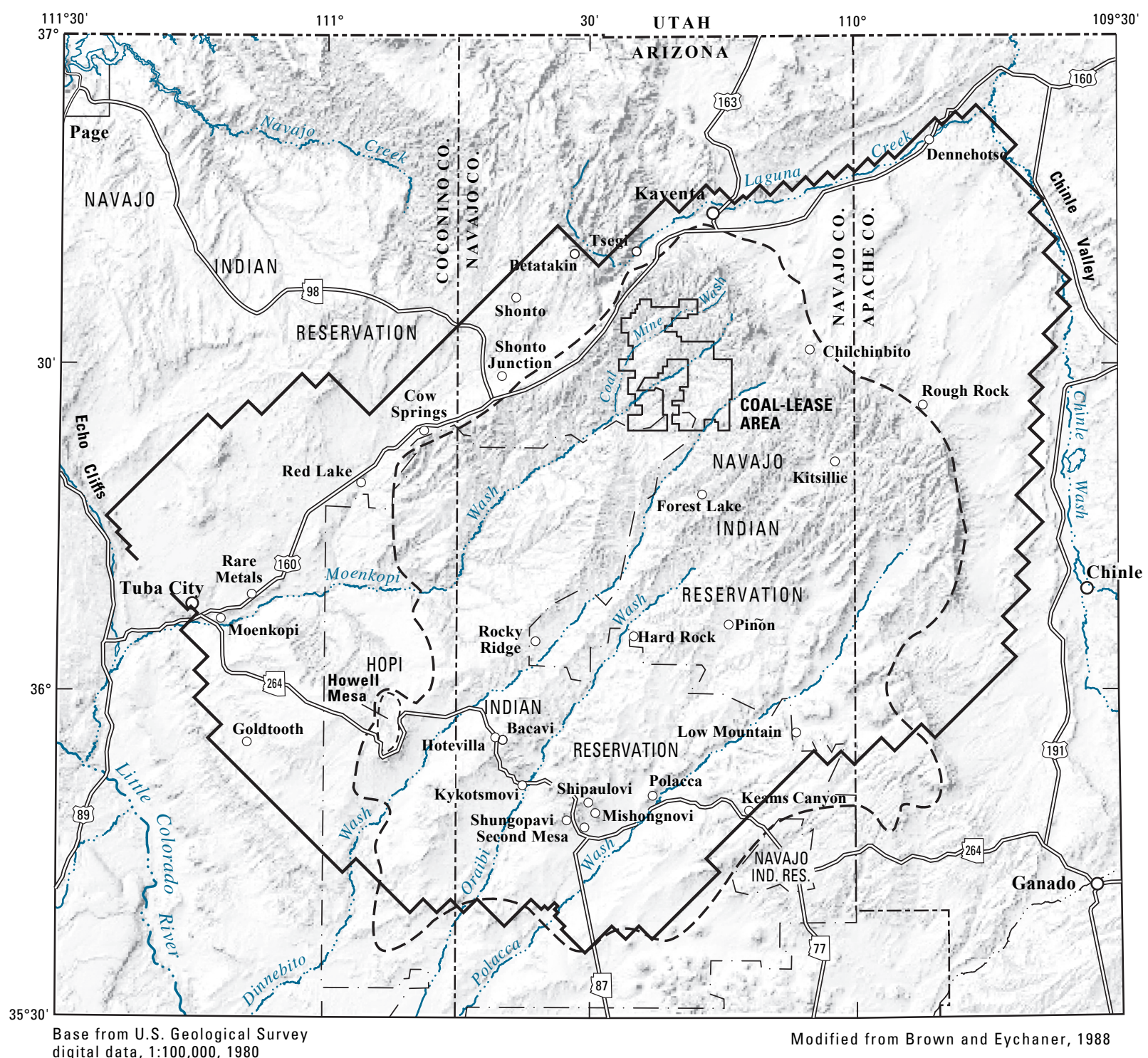

digital data, 1:100,000,1980

Lambert Conformal Conic projection

Standard parallels $29^{\circ} 30^{\prime}$ and $45^{\circ} 30^{\prime}$
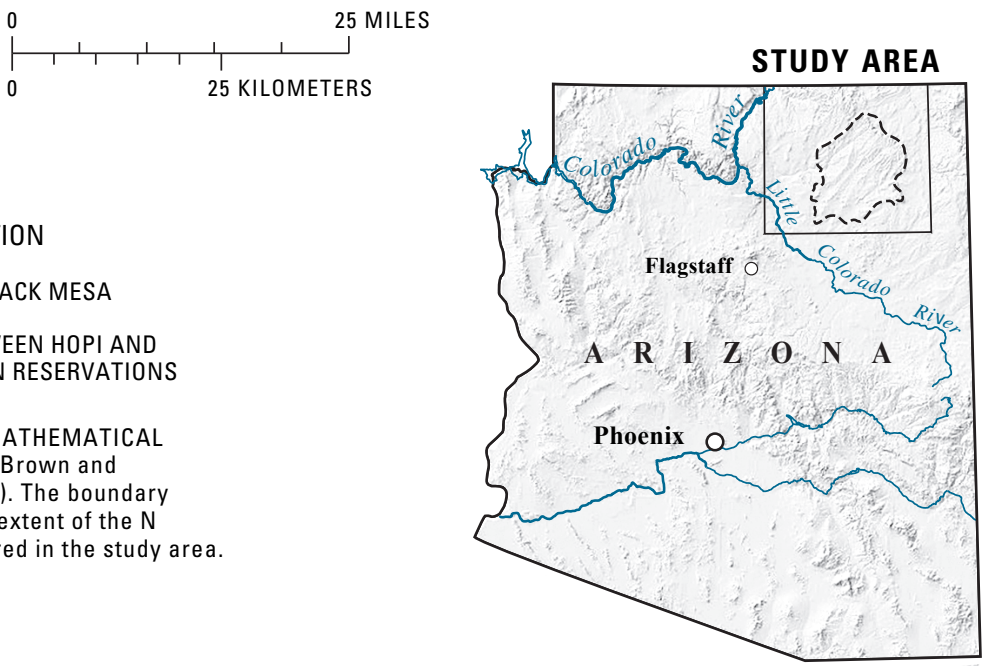

Figure 1. Location of water monitoring program study area, Black Mesa, northeastern Arizona. 


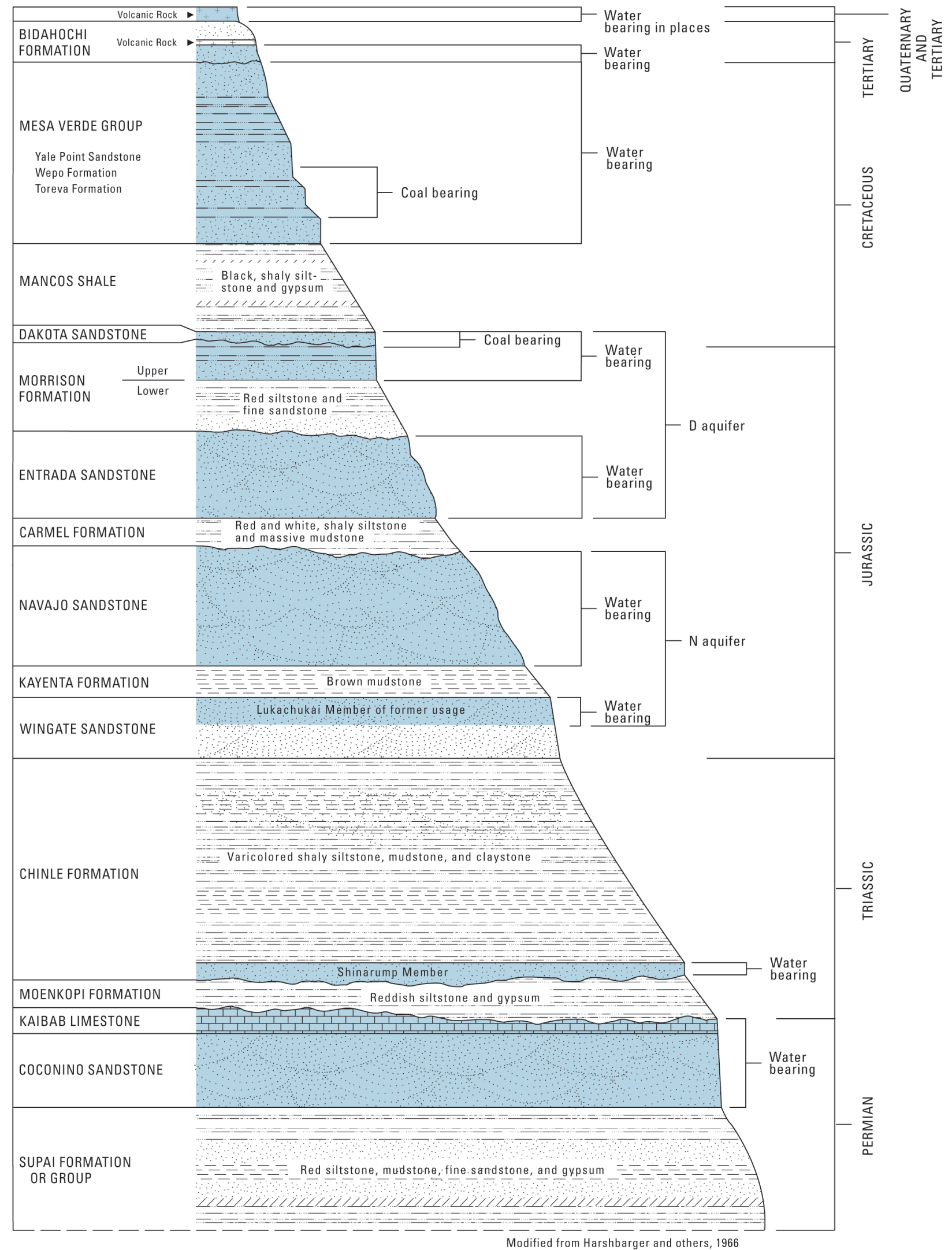

Figure 2. Rock formation and hydrogeologic units of the Black Mesa area, northeastern Arizona. The $\mathrm{N}$ aquifer is approximately 1,000 feet thick. 


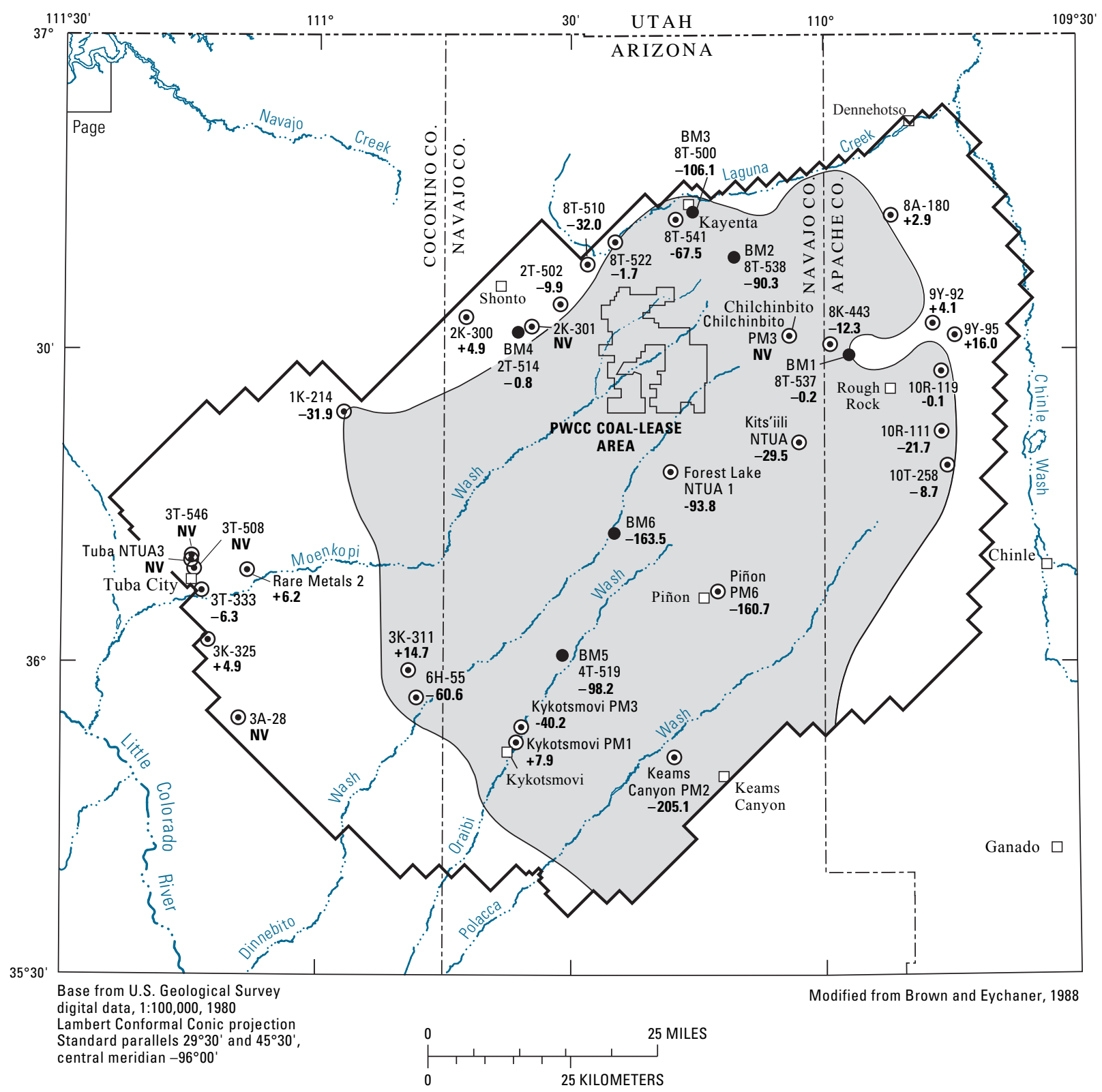

CONFINED AND UNCONFINED CONDITIONS IN THE N AQUIFER

\section{EXPLANATION}

Confined area within the boundary of the mathematical model boundary Unconfined area within the boundary
of the mathematical model boundary APPROXIMATE BOUNDARY BETWEEN CONFINED AND UNCONFINED CONDITIONS From Brown and Eychaner (1988)

○ WELL IN WHICH DEPTH TO 2K-300 WATER WAS MEASURED K-300, is Bure au Bureau of Indian Affairs site number; second entry, +4.9 , is change in water level, in feet, between measurement made during the prestress period and measurement made during 2007. NV, site not visited

CONTINUOUS WATER-LEVEL RECORDING SITE (OBSERVATION WELL) MAINTAINED BY THE U.S. GEOLOGICAL SURVEY-First entry, BM2, is U.S. Geological Survey well number; second entry, $8 \mathrm{~T}-538$, is Bureau of Indian Affairs site number; third entry, -89.1, is change in water level, in feet, from simulated prestress period to 2007 MODEL-From Brown and Eychaner (1988). The boundary delineates the unconfined area of the $\mathrm{N}$ aquifer.

Figure 3. Water-level changes in N aquifer wells from the prestress period prior to 1965 to 2007, Black Mesa area, northeastern Arizona. 
Within the Black Mesa study area, Peabody Western Coal Company (PWCC) is the principal industrial water user, and the Navajo Nation and Hopi Tribe are the principal municipal water users. Withdrawals from the $\mathrm{N}$ aquifer in the Black Mesa area have been increasing during the last 40 years. PWCC began operating a strip mine in the northern part of the study area in 1968. The quantity of water pumped by PWCC increased from about 100 acre-ft in 1968 to a maximum of 4,740 acre-ft in 1982. In 2005 PWCC pumped about 4,480 acre-ft of water. Withdrawals from the $\mathrm{N}$ aquifer for municipal use increased from an estimated 250 acre-ft in 1968 to 2,850 acre-ft in 2005. The period before appreciable ground-water withdrawals began for mining or municipal purposes (about 1965) is referred to in this report as the prestress period. PWCC plans on pumping approximately 1,000 to 1,500 acre-ft per year, primarily for dust control. In 2006 PWCC pumped about 1,170 acre-ft.

The members of the Navajo Nation and the Hopi Tribe have been concerned about the long-term effects of withdrawals from the $\mathrm{N}$ aquifer on available water supplies, on stream and spring discharge, and on ground-water chemistry. In 1971, these water-supply concerns led to the establishment of a monitoring program for the water resources in the Black Mesa area by the U.S. Geological Survey (USGS) in cooperation with the Arizona Department of Water Resources (ADWR). In 1983, the Bureau of Indian Affairs (BIA) joined the cooperative effort. Since 1983, the Navajo Tribal Utility Authority (NTUA); PWCC; the Hopi Tribe; the Western Navajo Agency; the Chinle Agency; and the Hopi Agency of the BIA have assisted in the collection of hydrologic data.

\section{Purpose and Scope}

This report presents results of ground-water, surfacewater, and water-chemistry monitoring in the Black Mesa area from January 2006 to September 2007. Results from the monitoring program are designed to determine the effects of industrial and municipal pumpage from the $\mathrm{N}$ aquifer on ground-water levels, stream and spring discharge, and groundwater chemistry. Continuous and periodic ground-water and surface-water data are collected. Ground-water data include water levels, spring discharge rates, and water chemistry. Surface-water data include discharge rates at four continuousrecord streamflow-gaging stations.

\section{Previous Investigations}

Twenty-four progress reports on the Black Mesa area monitoring program have been prepared by the USGS (U.S. Geological Survey, 1978; G.W. Hill, Hydrologist, written commun., 1982, 1983; Hill, 1985; Hill and Whetten, 1986; Hill and Sottilare, 1987; Hart and Sottilare, 1988, 1989; Sottilare, 1992; Littin, 1992, 1993; Littin and Monroe, 1995a,b, 1996, 1997; Littin and others, 1999; Truini and others, 2000;
Thomas and Truini, 2000; Thomas, 2002a,b; Truini and Thomas, 2004; Truini and others, 2005; Truini and Macy, 2006; and Truini and Macy, 2007). Most of the data from the Black Mesa area monitoring program are contained in these progress reports and in the USGS National Inventory System (NWIS) database (http://waterdata.usgs.gov/az/nwis/). Streamdischarge and periodic water-quality data collected from Moenkopi Wash before the 1982 water year, were published by the USGS (1963-64a, b; 1965-74a, b; and 1976-83). Stream-discharge data from water years 1983 to 2003 for Moenkopi Wash at Moenkopi, Dinnebito Wash near Sand Springs, Polacca Wash near Second Mesa, Laguna Creek, and Pasture Canyon Spring in the Black Mesa area were published in White and Garrett (1984, 1986, 1987, 1988), Wilson and Garrett (1988, 1989), Boner and others (1989, 1990, 1991, 1992), Smith and others (1993, 1994, 1995, 1996, 1997), Tadayon and others (1998, 1999, 2000, 2001), McCormack and others (2002, 2003), Fisk and others (2004, 2005), and online at (http://wdr.water.usgs.gov/wy2006/search.jsp) in the 2006 annual data report. Before the monitoring program, a large data-collection effort in the 1950s resulted in a compilation of well and spring data for the Navajo and Hopi Indian Reservations (Davis and others, 1963).

Many interpretive studies have investigated the hydrology of the Black Mesa area. Cooley and others (1969) made the first comprehensive evaluation of the regional hydrogeology of the Black Mesa area. Eychaner (1983) developed a two-dimensional numerical model of ground-water flow in the $\mathrm{N}$ aquifer. Brown and Eychaner (1988) recalibrated Eychaner's model by using a finer grid and revised estimates of selected aquifer characteristics. GeoTrans (1987) also developed a two-dimensional numerical model of the $\mathrm{N}$ aquifer in the 1980s. In the late 1990s, HSIGeoTrans and Waterstone Environmental Hydrology and Engineering (1999) developed a detailed three-dimensional numerical model of the $\mathrm{D}$ and $\mathrm{N}$ aquifers.

Kister and Hatchett (1963) made the first comprehensive evaluation of the chemistry of water collected from wells and springs in the Black Mesa area. HSIGeoTrans (1993) evaluated the major-ion and isotopic chemistry of the D and $\mathrm{N}$ aquifers. Lopes and Hoffmann (1997) analyzed ground-water ages, recharge, and hydraulic conductivity of the $\mathrm{N}$ aquifer by using geochemical techniques. Zhu and others (1998) estimated ground-water recharge in the Black Mesa area by using isotopic data and flow estimates from the $\mathrm{N}$-aquifer model developed by GeoTrans (1987). Zhu (2000) estimated recharge by using the same isotopic data from the GeoTrans model, but added numerical-flow and transport modeling to the method. Truini and Longsworth (2003) described the hydrogeology of the D aquifer and the movement and ages of ground water in the Black Mesa area by using data from geochemical and isotopic analyses. Truini and Macy (2005) address leakage through the confining unit between the D aquifer and the $\mathrm{N}$ aquifer in a characterization of the Carmel Formation. 


\section{Hydrologic Data}

In 2006-07, the Black Mesa area monitoring program included measuring depth to ground water, measuring discharge in streams and springs, and collecting and analyzing water samples from wells and springs. Annual discharge measurements were made at 1 spring, and annual ground-water level measurements were made at 30 wells. Six of the 30 annual wells are continuous-recording observation wells that have been upgraded for telemetry. The water-level data from these six continuousrecording observation wells are available on the World Wide Web (http://waterdata.usgs.gov/az/nwis/rt). Spring discharges and ground-water levels were measured from January to April 2007. Ground-water samples were collected from 1 well and 1 spring in April and May 2007 and were analyzed for chemical constituents. Annual ground-water withdrawal data are collected from 28 well systems within the NTUA, BIA, and Hopi municipal systems and the PWCC industrial well field, however, the 2006 NTUA withdrawal data were unavailable. Identification information for the 35 wells used for water-level measurements and water-quality sampling is shown in table 1.

\section{Withdrawals from the $\mathbf{N}$ Aquifer}

Withdrawals from the $\mathrm{N}$ aquifer are separated into three categories: (1) industrial withdrawals from the confined area, (2) municipal withdrawals from the confined area, and (3) municipal withdrawals from the unconfined areas. The industrial category includes eight wells in the PWCC well field in the northern Black Mesa area. The BIA, NTUA, and Hopi Tribe operate about 70 municipal wells that are combined into 28 well systems. Information about withdrawals from the $\mathrm{N}$ aquifer is compiled primarily on the basis of metered data from individual wells operated by the BIA, NTUA, and Hopi Tribe.

The total withdrawals are often a combination of meter readings from the agencies that operate the wells within the different systems. The NTUA annual withdrawal totals for the metered data were unavailable in 2006 due to an upgrade within the NTUA computer network. Because NTUA data is often combined with BIA data for the total withdrawals in a well system, withdrawals will not be published in this year's annual report.

\section{Ground-Water Levels in the N Aquifer}

Ground water in the $\mathrm{N}$ aquifer is under confined conditions in the central part of the study area and under unconfined or water-table conditions around the periphery (fig. 3). From the recharge areas near Shonto, the ground water moves radially to the southwest toward Tuba City, to the south toward the Hopi Reservation, and to the east toward Rough Rock and Dennehotso (Eychaner, 1983).

Ground-water levels are measured once a year and compared with levels from previous years to determine changes over time. Only water levels from municipal and stock wells
Table 1. Identification numbers and names of monitoring program study wells, 2006-07, Black Mesa area, northeastern Arizona.

[Dashes indicate no data]

\begin{tabular}{|c|c|c|}
\hline $\begin{array}{l}\text { U.S. Geological Survey } \\
\text { identification number }\end{array}$ & $\begin{array}{l}\text { Common name } \\
\text { or location }\end{array}$ & $\begin{array}{l}\text { Bureau of } \\
\text { Indian Affairs } \\
\text { site number }\end{array}$ \\
\hline 355023110182701 & Keams Canyon PM2 & - \\
\hline 355230110365801 & Kykotsmovi PM1 & - \\
\hline 355428111084601 & Goldtooth & $3 \mathrm{~A}-28$ \\
\hline 355648110475501 & Howell Mesa & $6 \mathrm{H}-55$ \\
\hline 355924110485001 & Howell Mesa & $3 \mathrm{~K}-311$ \\
\hline 360055110304001 & BM observation well 5 & $4 \mathrm{~T}-519$ \\
\hline 360217111122601 & Tuba City & $3 \mathrm{~K}-325$ \\
\hline 360614110130801 & Piñon PM6 & - \\
\hline 360734111144801 & Tuba City & $3 \mathrm{~T}-333$ \\
\hline 360918111080701 & Tuba City Rare Metals 2 & - \\
\hline 361225110240701 & BM observation well 6 & - \\
\hline 361737110180301 & Forest Lake NTUA 1 & $4 \mathrm{~T}-523$ \\
\hline 361832109462701 & Rough Rock & $10 \mathrm{~T}-258$ \\
\hline 362043110030501 & Kits'illi NTUA 2 & - \\
\hline 362149109463301 & Rough Rock & 10R-111 \\
\hline 362901110234101 & Peabody 5 & - \\
\hline 362406110563201 & White Mesa Arch & $1 \mathrm{~K}-214$ \\
\hline 362936109564101 & BM observation well 1 & $8 \mathrm{~T}-537$ \\
\hline 363013109584901 & Sweetwater Mesa & $8 K-443$ \\
\hline 363103109445201 & Rough Rock & $9 Y-95$ \\
\hline 363143110355001 & BM observation well 4 & 2T-514 \\
\hline 363213110342001 & Shonto Southeast & $2 \mathrm{~K}-301$ \\
\hline 363232109465601 & Rough Rock & $9 Y-92$ \\
\hline 363423110305501 & Shonto Southeast & 2T-502 \\
\hline 363309110420501 & Shonto & $2 \mathrm{~K}-300$ \\
\hline 363727110274501 & Long House Valley & $8 \mathrm{~T}-510$ \\
\hline 363850110100801 & BM observation well 2 & 8T-538 \\
\hline 364226110171701 & Kayenta West & $8 \mathrm{~T}-541$ \\
\hline 364248109514601 & Northeast Rough Rock & $8 \mathrm{~A}-180$ \\
\hline 364338110154601 & BM observation well 3 & $8 \mathrm{~T}-500$ \\
\hline 364034110240001 & Marsh Pass & $8 \mathrm{~T}-522$ \\
\hline
\end{tabular}

that were not considered to have been recently pumped, influenced by nearby pumping, or blocked or obstructed were used for comparison. During January 2007 to June 2007, water levels in 28 of 30 wells that were visited for annual measurements met these criteria (table 2). Six of the 30 wells are continuous-recording observation wells, and water levels were measured manually in these 6 wells twice between April 2006 and June 2007. Twenty-eight of 30 water levels measured in 2007 were compared with water levels for the same wells 
Table 2. Water-level changes in monitoring program wells completed in the $\mathrm{N}$ aquifer, Black Mesa area, northeastern Arizona, prestress period (prior to 1965) to 2007.

\begin{tabular}{|c|c|c|c|c|c|c|c|}
\hline \multirow{2}{*}{ Common name or location } & \multirow{2}{*}{$\begin{array}{l}\text { Bureau of } \\
\text { Indian Affairs } \\
\text { site number }\end{array}$} & \multicolumn{2}{|c|}{$\begin{array}{c}\text { Change in water level from } \\
\text { preceding year, in feet }\end{array}$} & \multirow{2}{*}{$\begin{array}{c}\text { Water level 2007', } \\
\text { in feet } \\
\text { below land surface }\end{array}$} & \multicolumn{2}{|c|}{$\begin{array}{l}\text { Prestress period } \\
\text { water level }\end{array}$} & \multirow{2}{*}{$\begin{array}{l}\text { Change in water } \\
\text { level from } \\
\text { prestress period } \\
\text { to } 2007 \text {, in feet }\end{array}$} \\
\hline & & 2006 & 2007 & & \begin{tabular}{|c|}
$\begin{array}{c}\text { Feet below } \\
\text { land surface }\end{array}$ \\
\end{tabular} & Date & \\
\hline \multicolumn{8}{|c|}{ Unconfined areas } \\
\hline BM observation well $1^{3}$ & $8 \mathrm{~T}-537$ & +0.2 & 0.0 & 374.2 & 374.0 & $\left({ }^{1}\right)$ & -0.2 \\
\hline BM observation well $4^{3}$ & $2 \mathrm{~T}-514$ & -0.1 & 0.0 & 216.8 & 216.0 & $\left({ }^{1}\right)$ & -0.8 \\
\hline Goldtooth & $3 \mathrm{~A}-28$ & -4.0 & $\left({ }^{3}\right)$ & $\left({ }^{3}\right)$ & 230.0 & $10-29-53$ & $\left({ }^{3}\right)$ \\
\hline Long House Valley & $8 \mathrm{~T}-510$ & -0.3 & -1.4 & 131.4 & 99.4 & $08-22-67$ & -32.0 \\
\hline Northeast Rough Rock & $8 \mathrm{~A}-180$ & -0.4 & +0.4 & 44.0 & 46.9 & $11-13-53$ & +2.9 \\
\hline Rough Rock & 9Y-95 & -4.9 & +5.9 & 103.5 & 119.5 & 08-03-49 & +16.0 \\
\hline Rough Rock & 9Y-92 & -0.6 & +0.9 & 164.7 & 168.8 & $12-13-52$ & +4.1 \\
\hline Shonto & $2 \mathrm{~K}-300$ & +0.0 & -0.3 & 171.6 & 176.5 & $06-13-50$ & +4.9 \\
\hline Shonto Southeast & $2 \mathrm{~K}-301$ & -0.8 & $\left({ }^{3}\right)$ & $\left({ }^{3}\right)$ & 283.9 & $12-10-52$ & $\left({ }^{3}\right)$ \\
\hline Shonto Southeast & 2T-502 & -1.4 & +0.5 & 415.7 & 405.8 & $08-22-67$ & -9.9 \\
\hline Tuba City & 3T-333 & -0.6 & 0.0 & 29.3 & 23.0 & $12-02-55$ & -6.3 \\
\hline Tuba City & $3 \mathrm{~K}-325$ & -0.5 & -0.4 & 203.1 & 208.0 & $06-30-55$ & +4.9 \\
\hline Tuba City Rare Metals 2 & - & +0.6 & +0.2 & 50.8 & 57.0 & 09-24-55 & +6.2 \\
\hline Tuba City NTUA 1 & $3 \mathrm{~T}-508$ & $\left({ }^{2}\right)$ & $\left({ }^{3}\right)$ & $\left({ }^{3}\right)$ & 29.0 & $02-12-69$ & $\left({ }^{3}\right)$ \\
\hline Tuba City NTUA 3 & - & $\left({ }^{2}\right)$ & $\left({ }^{3}\right)$ & $\left({ }^{3}\right)$ & 34.2 & $11-08-71$ & $\left({ }^{3}\right)$ \\
\hline Tuba City NTUA 4 & $3 \mathrm{~T}-546$ & $\left({ }^{2}\right)$ & $\left({ }^{3}\right)$ & $\left({ }^{3}\right)$ & 33.7 & 08-06-71 & $\left({ }^{3}\right)$ \\
\hline \multicolumn{8}{|c|}{ Confined area } \\
\hline BM observation well $2^{3}$ & $8 \mathrm{~T}-538$ & -1.5 & -2.5 & 215.3 & 125.0 & (1) & -90.3 \\
\hline $\mathrm{BM}$ observation well $3^{3}$ & $8 \mathrm{~T}-500$ & -3.5 & -2.5 & 161.1 & 55.0 & 04-29-63 & -106.1 \\
\hline BM observation well $5^{3}$ & $4 \mathrm{~T}-519$ & -3.2 & -3.9 & 422.2 & 324.0 & (1) & -98.2 \\
\hline BM observation well $6^{3}$ & - & -3.6 & -1.8 & 860.5 & 697.0 & (1) & -163.5 \\
\hline Forest Lake NTUA 1 & $4 \mathrm{~T}-523$ & $\left({ }^{2}\right)$ & +0.3 & 1189.8 & $1,096^{\mathrm{R}}$ & $05-21-82$ & -93.8 \\
\hline Howell Mesa & $3 \mathrm{~K}-311$ & -1.4 & +2.1 & 448.3 & 463.0 & $11-03-53$ & +14.7 \\
\hline Howell Mesa & $6 \mathrm{H}-55$ & -1.1 & +0.3 & 272.6 & 212.0 & $07-08-54$ & -60.6 \\
\hline Kayenta West & $8 \mathrm{~T}-541$ & $\left({ }^{2}\right)$ & +8.2 & 297.5 & 230.0 & $03-17-76$ & -67.5 \\
\hline Keams Canyon PM2 & - & -2.9 & -8.9 & 497.6 & 292.5 & 06-10-70 & -205.1 \\
\hline Kitsillie NTUA 2 & - & -3.5 & -3.4 & 1327.4 & $1,297.9$ & 01-14-99 & -29.5 \\
\hline Kykotsmovi PM1 & - & +1.7 & +0.4 & 212.1 & 220.0 & $05-20-67$ & +7.9 \\
\hline Kykotsmovi PM3 & - & $\left({ }^{2}\right)$ & $\left({ }^{2}\right)$ & 250.2 & 210.0 & $08-28-68$ & -40.2 \\
\hline Marsh Pass & $8 \mathrm{~T}-522$ & +1.0 & +0.2 & 127.2 & 125.5 & $02-07-72$ & -1.7 \\
\hline Piñon PM6 & - & -8.0 & -5.9 & 904.3 & 743.6 & $05-28-70$ & -160.7 \\
\hline Rough Rock & 10R-119 & $\left({ }^{2}\right)$ & $\left({ }^{2}\right)$ & 256.7 & 256.6 & $12-02-53$ & -0.1 \\
\hline Rough Rock & 10T-258 & -0.1 & -0.2 & 309.7 & 301.0 & 04-14-60 & -8.7 \\
\hline Rough Rock & 10R-111 & +3.1 & +0.3 & 191.7 & 170.0 & $08-04-54$ & -21.7 \\
\hline Sweetwater Mesa & $8 \mathrm{~K}-443$ & -0.9 & +0.2 & 541.7 & 529.4 & 09-26-67 & -12.3 \\
\hline White Mesa Arch & $1 \mathrm{~K}-214$ & -0.3 & +0.4 & 219.9 & 188.0 & $06-04-53$ & -31.9 \\
\hline
\end{tabular}

${ }^{1}$ Continuous recorder. Except for well BM3, prestress period water levels were estimated from a ground-water model (Brown and Eychaner, 1988).

${ }^{2}$ Cannot be determined because at least one of the water-level measurements is not available.

${ }^{3}$ Site not visited in 2006-07.

Note: Numbers with superscript R are reported. 
Table 3. Well-construction characteristics, depth to top of $\mathrm{N}$ aquifer, and type of data collected for wells in monitoring program, Black Mesa area, northeastern Arizona, 2006-07.

\begin{tabular}{|c|c|c|c|c|c|c|}
\hline $\begin{array}{l}\text { Bureau of Indian Affairs site } \\
\text { number and (or) common } \\
\text { name }\end{array}$ & $\begin{array}{c}\text { Date well was } \\
\text { completed }\end{array}$ & $\begin{array}{l}\text { Land-surface } \\
\text { elevation, } \\
\text { in feet }\end{array}$ & \begin{tabular}{|c|} 
Well depth, in \\
feet below land \\
surface
\end{tabular} & $\begin{array}{c}\text { Screened/open } \\
\text { interval(s), in feet } \\
\text { below land surface }\end{array}$ & $\begin{array}{c}\text { Depth to top of } \mathbf{N} \\
\text { aquifer, in feet } \\
\text { below land surface }\end{array}$ & $\begin{array}{l}\text { Type of data } \\
\text { collected }\end{array}$ \\
\hline $\begin{array}{l}8 \mathrm{~T}-537 \\
\text { (BM observation well 1) }\end{array}$ & $02-01-72$ & 5,864 & 851 & $\begin{array}{c}300-360 ; 400-420 \\
500-520 ; 600-620 \\
730-780\end{array}$ & 290 & Water level \\
\hline $\begin{array}{l}\text { 8T-538 } \\
\text { (BM observation well 2) }\end{array}$ & 01-29-72 & 5,656 & 1,338 & $470-1,338$ & 452 & Water level \\
\hline $\begin{array}{l}\text { 8T-500 } \\
\text { (BM observation well 3) }\end{array}$ & 07-29-59 & 5,724 & 868 & $712-868$ & 155 & Water level \\
\hline $\begin{array}{l}\text { 2T-514 } \\
\text { (BM observation well 4) }\end{array}$ & $02-15-72$ & 6,320 & 400 & $250-400$ & 160 & Water level \\
\hline $\begin{array}{l}\text { 4T-519 } \\
\text { (BM observation well 5) }\end{array}$ & $02-25-72$ & 5,869 & 1,683 & $1,521-1,683$ & 1,520 & Water level \\
\hline BM observation well 6 & $01-31-77$ & 6,332 & 2,507 & $1,954-2,506$ & 1,950 & Water level \\
\hline $1 \mathrm{~K}-214$ & $05-26-50$ & 5,771 & 356 & $168-356$ & 250 & Water level \\
\hline $2 \mathrm{~K}-300$ & ${ }^{3} 06-00-50$ & 6,264 & 300 & $260-300$ & 0 & Water level \\
\hline $2 \mathrm{~K}-301$ & $06-12-50$ & 6,435 & 500 & $318-328 ; 378-500$ & 230 & Water level \\
\hline $2 \mathrm{~T}-502$ & $08-10-59$ & 6,670 & 523 & $12-523$ & ${ }^{2} 5$ & Water level \\
\hline $3 \mathrm{~A}-28$ & $04-19-35$ & 5,381 & 358 & $\left({ }^{4}\right)$ & 60 & Water level \\
\hline $3 \mathrm{~K}-311$ & ${ }^{3} 11-00-34$ & 5,855 & 745 & $380-395 ; 605-745$ & 615 & Water level \\
\hline $3 \mathrm{~K}-325$ & $06-01-55$ & 5,250 & 450 & $75-450$ & 230 & Water level \\
\hline $3 \mathrm{~T}-333$ & $12-02-55$ & 4,940 & 229 & $63-229$ & ${ }^{2} 4$ & Water level \\
\hline $\begin{array}{l}\text { 4T-523 } \\
\text { (Forest Lake NTUA 1) }\end{array}$ & $10-01-80$ & 6,654 & 2,674 & $\begin{array}{r}1,870-1,910 ; 2,070- \\
2,210 ; 2,250-2,674 \\
\end{array}$ & $\left({ }^{5}\right)$ & $\begin{array}{l}\text { Water level, } \\
\text { withdrawals }\end{array}$ \\
\hline $6 \mathrm{H}-55^{6}$ & $12-08-44$ & 5,635 & 361 & $310-335$ & ${ }^{6} 310$ & Water level \\
\hline $8 \mathrm{~A}-180$ & $01-20-39$ & 5,200 & 107 & $60-107$ & ${ }^{2} 40$ & Water level \\
\hline $8 \mathrm{~K}-443$ & $08-15-57$ & 6,024 & 720 & $619-720$ & 590 & Water level \\
\hline $8 \mathrm{~T}-510$ & $02-11-63$ & 6,262 & 314 & $130-314$ & ${ }^{2} 125$ & Water level \\
\hline $8 \mathrm{~T}-522$ & ${ }^{3} 07-00-63$ & 6,040 & 933 & $180-933$ & 480 & Water level \\
\hline $8 \mathrm{~T}-541$ & $03-17-76$ & 5,885 & 890 & $740-890$ & 700 & Water level \\
\hline $9 \mathrm{Y}-92$ & $01-02-39$ & 5,615 & 300 & $154-300$ & ${ }^{2} 50$ & Water level \\
\hline 9Y-95 & $11-05-37$ & 5,633 & 300 & $145-300$ & ${ }^{2} 68$ & Water level \\
\hline 10R-111 & $04-11-35$ & 5,757 & 360 & $267-360$ & 210 & Water level \\
\hline 10R-119 & $12-02-53$ & 5,775 & 360 & $\left({ }^{4}\right)$ & 235 & Water level \\
\hline $10 \mathrm{~T}-258$ & $04-12-60$ & 5,903 & 670 & $465-670$ & 460 & Water level \\
\hline Peabody 5 & $00-00-68$ & 6,585 & 3,737 & $2,091-3,735$ & 3,140 & $\begin{array}{l}\text { Water } \\
\text { hemistry }\end{array}$ \\
\hline Keams Canyon PM2 & ${ }^{3} 05-00-70$ & 5,809 & 1,106 & $906-1,106$ & 900 & $\begin{array}{l}\text { Water level, } \\
\text { withdrawals }\end{array}$ \\
\hline Kits'iili NTUA 2 & $10-30-93$ & 6,780 & 2,549 & $\begin{array}{c}2,217-2,223 ; 2,240- \\
2,256 ; 2,314-2,324 ; \\
2,344-2,394 ; \\
2,472-2,527\end{array}$ & 2,205 & Withdrawals \\
\hline Kykotsmovi PM1 & $02-20-67$ & 5,657 & 995 & $655-675 ; 890-990$ & 880 & $\begin{array}{l}\text { Water level, } \\
\text { withdrawals }\end{array}$ \\
\hline Kykotsmovi PM3 & 10-14-77 & 5,760 & 1,155 & $950-1,155$ & 890 & Withdrawals \\
\hline Piñon PM6 & ${ }^{3} 02-00-70$ & 6,397 & 2,248 & $1,895-2,243$ & 1,870 & $\begin{array}{l}\text { Water level, } \\
\text { witdrawals }\end{array}$ \\
\hline Tuba City Rare Metals 2 & ${ }^{3} 09-00-55$ & 5,108 & 705 & $100-705$ & 255 & Water level \\
\hline
\end{tabular}

${ }^{1}$ Depth to top of $\mathrm{N}$ aquifer from Eychaner (1983) and Brown and Eychaner (1988).

${ }^{2}$ All material between land surface and top of the $\mathrm{N}$ aquifer is unconsolidated—soil, alluvium, or dune sand.

${ }^{3} 00$, indicates month or day is unknown.

${ }^{4}$ Screened and (or) open intervals are unknown.

${ }^{5}$ Depth to top of $\mathrm{N}$ aquifer was not estimated.

${ }^{6}$ Developed into the $\mathrm{D}$ aquifer only. 
measured in 2006. Water levels measured in 2007 in two of the wells, Kykotsmovi PM3 and 10R-119 at Rough Rock, could not be compared to 2006 water levels because measurements were not available for these wells in 2006.

The wells used for water-level measurements are distributed throughout the study area (fig. 3). All but one of the wells is completed in the $\mathrm{N}$ aquifer; however, the characteristics of the wells vary considerably. Well 6H-55 was previously thought to be completed in the $\mathrm{N}$ aquifer, but is actually completed in the D aquifer. Construction dates range from 1934 to 1993 , total well depths range from $107 \mathrm{ft}$ near Dennehotso (8A-107), to 3,735 ft near PWCC, and depths to the top of the $\mathrm{N}$ aquifer range from $0 \mathrm{ft}$ near Tuba City, to $3,140 \mathrm{ft}$ near PWCC, (table 3).

From 2006 to 2007, water levels decreased in 11 of the 28 wells for which comparisons could be made (table 2). The median water-level change in the 28 wells was $0.1 \mathrm{ft}$ (table 4). From 2006 to 2007, water levels declined in 3 of the 11 wells measured in the unconfined parts of the aquifer (table 2). The median water-level change was $0.0 \mathrm{ft}$ (table 4). Water-level changes in the unconfined part of the aquifer ranged from $-1.4 \mathrm{ft}$ at $8 \mathrm{~T}-510$ near Long House Valley to $5.9 \mathrm{ft}$ at $9 \mathrm{Y}-95$ in Rough Rock (table 2). In the confined area, water levels declined in 8 of 17 wells measured from 2006 to 2007. The median water-level change was $0.2 \mathrm{ft}$ (table 4). Water-level changes in the confined part of the aquifer ranged from -8.9 $\mathrm{ft}$ at Keams Canyon PM2 to $8.2 \mathrm{ft}$ at 8T-541 in Kayenta West (table 2).

From the pre-stress period (prior to 1965) to 2007, the median water-level change in 30 wells was $-11.1 \mathrm{ft}$ (table 4). Water levels in 11 unconfined wells had a median change of $2.9 \mathrm{ft}$. Water-level changes in the unconfined part of the aquifer ranged from $-32.0 \mathrm{ft}$ at $8 \mathrm{~T}-510$ near Long House Valley to $16.0 \mathrm{ft}$ at 9Y-95 in Rough Rock (table 2). Water levels in 19 wells in the confined part of the aquifer had a median change of -40.2 ft (table 4). Water-level changes in the confined part of the aquifer ranged from $-205.1 \mathrm{ft}$ at Keams Canyon PM2 to $14.7 \mathrm{ft}$ at $3 \mathrm{~K}-311$ (fig. 3 and table 2).

Table 4. Median changes in water levels in monitoring program wells, 2006-07 and prestress period (prior to 1965) to 2007, N aquifer, Black Mesa area, northeastern Arizona.

\begin{tabular}{clcc}
\hline \multicolumn{1}{c}{ Years } & $\begin{array}{c}\text { Aquifer } \\
\text { conditions }\end{array}$ & $\begin{array}{c}\text { Number } \\
\text { of wells }\end{array}$ & $\begin{array}{c}\text { Median change in } \\
\text { water level, in feet }\end{array}$ \\
\hline $2006-07$ & All & 28 & 0.1 \\
& Unconfined & 11 & 0.0 \\
& Confined & 17 & 0.2 \\
Prestress-2007 & All & 30 & -11.1 \\
& Unconfined & 11 & 2.9 \\
& Confined & 19 & -40.2 \\
\hline
\end{tabular}

Hydrographs of ground-water levels in the annual-well network show the time trends of changes since the 1950s, 1960s, or 1970s (fig. 4). In most of the unconfined area, water levels have changed only slightly. Near Long House Valley, however, the water level in well 8T-510 has declined about $32 \mathrm{ft}$ (fig. 3). Water levels have declined in most of the confined area; however, the magnitudes of declines are varied. Larger declines have occurred near the municipal pumping centers (wells Piñon PM6, Keams Canyon PM2), or near the annual wells for PWCC (BM6). Smaller declines occur away from pumping centers in or near towns in the study area (wells 10T-258, 8K-443, 10R-111, 8T-522; fig. 3).

Hydrographs for the Black Mesa continuous-record observation wells show continuous water-levels since the early 1970s (fig. 5). Water levels in the two the wells in the unconfined areas (BM1 and BM4) have had small seasonal or year-to-year variation since 1972. Water levels in wells BM2, BM3, BM5, and BM6 in the confined area have consistently declined since the early to mid-1960s (fig. 5).

\section{Spring Discharge from the N Aquifer}

Ground water in the $\mathrm{N}$ aquifer discharges from many springs around the margins of Black Mesa. In 2007 one of four of the springs that have been measured annually was measured for discharge. Moenkopi School Spring is in the western part of the Black Mesa area (fig. 6). Discharge from Moenkopi School Spring was measured in April 2007 and compared to discharge data from previous years to determine changes over time (fig. 7). The measurements at Moenkopi School Spring are made volumetrically.

In 2007, measured discharge was $9.0 \mathrm{gal} / \mathrm{min}$ from Moenkopi School Spring (table 5). From 2006 to 2007, discharge decreased by 18.9 percent at Moenkopi School Spring. For the period of record, discharge measurements have fluctuated, indicating a decreasing trend (fig. 7).

\section{Surface-Water Discharge}

Surface-water discharge in the study area is a measurement of ground-water discharge to streams and direct runoff of rainfall or snowmelt. Ground water discharges to some channel reaches at a fairly constant rate throughout the year; however, the amount of ground-water discharge that results in surface flow is affected by seasonal fluctuations in water uptake by plants and by evapotranspiration (Thomas, 2002a). In contrast, the amount of rainfall or snowmelt runoff varies widely throughout the year. In the winter and spring, the amount and timing of snowmelt runoff are a result of the temporal variation in snow accumulation, air temperatures, and rate of snowmelt. Although rainfall can occur throughout the year, most rainfall runoff occurs during the summer months. The amount and timing of rainfall runoff depend on the intensity and duration of thunderstorms during the summer and cyclonic storms during the fall, winter, and spring. 
In 2006, discharge data were collected at four continuousrecording streamflow-gaging stations (tables 6-9). Data collection at these stations began in July 1976 (Moenkopi Wash at Moenkopi, 09401260), June 1993 (Dinnebito Wash near Sand Springs, 09401110), April 1994 (Polacca Wash near Second Mesa, 09400568), and August 2004 (Pasture Canyon Spring, 09401265; fig. 8 and table 10). The annual average discharges at the four streamflow-gaging stations vary during the periods of record (fig. 9A), and no trends are apparent for Moenkopi Wash, Polacca Wash, and Dinnebito Wash. No trends can be determined for Pasture Canyon Wash because the length of record in insufficient to calculate a trend. In 2006, annual average flows for Moenkopi Wash, Polacca Wash, and Dinnebito Wash increased (fig. 8).

The ground-water discharge component of total flow at the four streamflow-gaging stations was estimated by computing the median flow for 120 consecutive daily mean flows for four winter months-November, December, January, and February (fig. 9). Ground-water discharge was assumed to be constant throughout the year, and the median winter flow was assumed to represent the constant annual ground-water discharge. Most flow that occurs during the winter is groundwater discharge; rainfall and snowmelt runoff are minimal. Most of the precipitation in the winter falls as snow, and the cold temperatures prevent appreciable snowmelt. Evapotranspiration is at a minimum during the winter. Rather than the average flow, the median flow for November, December, January, and February is used to estimate ground-water discharge because the median is less affected by occasional winter runoff.

The median flow for November, December, January, and February is an index of ground-water discharge rather than an absolute estimate of ground-water discharge. A more rigorous and accurate estimate would involve detailed evaluations of streamflow hydrographs, flows into and out of bank storage, gain and loss of streamflow as it moves down the stream channel, and interaction of ground water in the $\mathrm{N}$ aquifer with ground water in the shallow alluvial aquifers in the stream valleys. The median winter flow, however, is useful as a consistent index for evaluating possible time trends in ground-water discharge.

Median winter flows were calculated for the 2007 water year; thus, daily mean flows for November and December 2006 were combined with daily mean flows for January and February 2007. These median winter flows were $2.3 \mathrm{ft}^{3} / \mathrm{s}$ for Moenkopi Wash at Moenkopi, $0.41 \mathrm{ft}^{3} / \mathrm{s}$ for Dinnebito Wash near Sand Springs, and $0.41 \mathrm{ft}^{3} / \mathrm{s}$ for Polacca Wash near Second Mesa (fig. 9A-C). For the period of record at each streamflow-gaging station, the median winter flows have generally remained constant as indicated by trends calculated by using the method of least squares (fig. $9 A-C$ ).

The annual average for precipitation measured at Betatakin National Park (Betatakin; fig. 1) from 1976 to 2006 is 12.6 in. (fig. $8 B$ ). Annual precipitation at Betatakin has been mostly less than average from 1995 through 2002 (11.4 in.); it was incomplete for 2003, above average for calendar year 2004 and 2005 (17.4), and below the average for calendar year 2006 (11.24 in.; fig. 8B).

\section{Water Chemistry}

Water samples for water-chemistry analyses are collected from selected wells and springs each year of the Black Mesa monitoring program. Field measurements are made, and water samples are analyzed for major ions, nutrients, iron, boron, and arsenic. Water-chemistry samples have been collected from 12 wells during each year of the program. Eight of the wells have been sampled every year, and the other four wells have been selected on the basis of a sampling rotation. In 2007 the well sampling sites were reduced, and a sample was collected only from Peabody 5. Since 1989, samples have been collected from the same 4 springs (Moenkopi School Spring, Pasture Canyon Spring, Unnamed spring near Dennehotso, and Burro Spring); however, in 2007, samples were collected only from Moenkopi School Spring. Long-term data for specific conductance, total dissolved solids, chloride, and sulfate for the wells and springs sampled each year are shown in the report published for that year. Historical data for other constituents for all the wells and springs in the Black Mesa study area are available from the USGS water-quality database (http://waterdata.usgs.gov/az/nwis/qw), or can be found in the past monitoring reports cited in the Previous Investigations section of this report.

\section{Water-Chemistry Data for Wells Completed in the N Aquifer}

The primary types of water in the $\mathrm{N}$ aquifer in the Black Mesa study area are calcium bicarbonate and sodium bicarbonate. Calcium bicarbonate water generally is in the recharge and unconfined areas of the northern and northwestern parts of the Black Mesa study area, and sodium bicarbonate water is generally in the area that is confined and downgradient to the south and east (Lopes and Hoffmann, 1997). In 2007, a water sample was collected from 1 well, Peabody 5 (fig. 6).

The sample from Peabody 5 yielded a sodium-bicarbonate type water and had a dissolved-solids concentration of $198 \mathrm{mg} / \mathrm{L}$ (fig. 10 and table 11). Concentrations of dissolved solids, chloride, and sulfate have varied for the period of record at Peabody 5 and indicate an increasing trend from 1968 to 2007 (fig. 11 and table 12). Concentrations of all the analyzed constituents in samples from Peabody 5 were less than current United States Environmental Protection Agency (USEPA) Maximum Contaminate Levels (MCLs) and Suggested Maximum Contaminate Levels (SMCLs; U.S. Environmental Protection Agency, 2002). 


\section{Water-Chemistry Data for Springs that Discharge from the N Aquifer}

In 2007, water samples were collected from Moenkopi School Spring in the southwestern part of the Black Mesa study area (fig. 7). Moenkopi School Spring discharges water from the unconfined part of the $\mathrm{N}$ aquifer. At Moenkopi School Spring, samples were collected from a horizontal metal pipe that is developed into the hillside to collect water from the spring.

The Moenkopi School Spring sample yielded a calciumbicarbonate-type water (fig. 10). The sample from the Moenkopi School Spring had a dissolved solids concentration of $238 \mathrm{mg} / \mathrm{L}$ (table 13). Concentrations of all the analyzed constituents in samples from Moenkopi School Spring were less than current USEPA MCLs and SMCLs (U.S. Environmental Protection Agency, 2002).

Increasing trends in concentrations of dissolved solids, chloride, and sulfate are evident in data from Moenkopi School Spring (table 14 and figs. 12A-C). Trend lines in figure 13 were generated by applying the statistical least squares method and are significantly different from zero.

\section{Summary}

The $\mathrm{N}$ aquifer is the major source of water for industrial and municipal users in the Black Mesa area of northeastern Arizona. Availability of water is an important issue in the Black Mesa area because of continued industrial and municipal use, a growing population, and precipitation of about 6 to 14 in. per year.

This report presents results of ground-water, surfacewater, and water-chemistry monitoring in the Black Mesa area from January 2006 to September 2007. The monitoring data for 2006-07 are compared with data for 2005-06 and with historical data from the 1950s to September 2007.

The total ground-water withdrawals are often a combination of meter readings from the agencies that operate the wells within the different systems. The NTUA yearly totals for the metered data were unavailable in 2006 due to an upgrade within the NTUA computer network. Because NTUA data is often combined with BIA data for the total withdrawals in a well system, withdrawals were not published in this year's annual report.

From 2006 to 2007, annually measured ground-water levels declined in 11 of 28 wells. The median water-level change for the 28 wells was $0.1 \mathrm{ft}$. In unconfined areas of the $\mathrm{N}$ aquifer, water levels declined in 3 of 11 annual wells, and the median change was $0.0 \mathrm{ft}$. In the confined area of the $\mathrm{N}$ aquifer, water levels declined in 8 of 16 wells, and the median change was $0.2 \mathrm{ft}$.

From the prestress period (prior to 1965) to 2007, the median ground-water level change in 30 wells was $-11.1 \mathrm{ft}$. Water levels in the 11 wells in the unconfined areas of the $\mathrm{N}$ aquifer had a median change of $2.9 \mathrm{ft}$, and the changes ranged from $-32.0 \mathrm{ft}$ to $16.0 \mathrm{ft}$. Water levels in the 19 wells in the confined area of the $\mathrm{N}$ aquifer had a median change of $-40.2 \mathrm{ft}$, and the changes ranged from $-205.1 \mathrm{ft}$ to $14.7 \mathrm{ft}$.

Discharge was measured annually at Moenkopi School Spring. Between 2006 and 2007, spring flow decreased by 18.9 percent. For about the past 12 years, discharge at Moenkopi School Spring has fluctuated, and the data indicates a decreasing trend.

Annual average discharges at four streamflow-gaging stations-Moenkopi Wash, Dinnebito Wash, Pasture Canyon Spring, and Polacca Wash-vary during the periods of record. No trends are apparent in streamflow at the five streamflowgaging stations. Median flows for November, December, January, and February of each water year are used as an index of ground-water discharge to those streams. For the period of record at each streamflow-gaging station, the median winter flows have generally remained even, showing neither a significant increase nor decrease in flows.

In 2007, water samples were collected from Peabody 5 well and analyzed for selected chemical constituents. Concentrations of dissolved solids, chloride, and sulfate have varied for the period of record, and the data indicate an increasing trend.

Dissolved-solids concentrations in water samples from Moenkopi School Spring were 238 mg/L. From the mid-1980s to 2007 , long-term data indicate increasing trends in concentrations of dissolved solids, chloride, and sulfate. 


\section{Selected References}

Boner, F.C., Davis, R.G., and Duet, N.R., 1992, Waterresources data for Arizona, water year 1991: U.S. Geological Survey Water-Data Report AZ-91-1, 411 p.

Boner, F.C., Garrett, W.B., and Konieczki, A.D., 1989, Waterresources data for Arizona, water year 1988: U.S. Geological Survey Water-Data Report AZ-88-1, 391 p.

Boner, F.C., Konieczki, A.D., and Davis, R.G., 1991, Waterresources data for Arizona, water year 1990: U.S. Geological Survey Water-Data Report AZ-90-1, 381 p.

Boner, F.C., Smith, C.F., Garrett, W.B., and Konieczki, A.D., 1990, Water-resources data for Arizona, water year 1989: U.S. Geological Survey Water-Data Report AZ-89-1, $383 \mathrm{p}$.

Brown, J.G., and Eychaner, J.H., 1988, Simulation of five ground-water withdrawal projections for the Black Mesa area, Navajo and Hopi Indian Reservations, Arizona: U.S. Geological Survey Water-Resources Investigations Report 88-4000, 51 p.

Cooley, M.E., Harshbarger, J.W., Akers, J.P., and Hardt, W.F., 1969, Regional hydrogeology of the Navajo and Hopi Indian Reservations, Arizona, New Mexico, and Utah: U.S. Geological Survey Professional Paper 521-A, 61 p.

Davis, G.E., Hardt, W.F., Thompson, L.K., and Cooley, M.E., 1963, Records of ground-water supplies, part 1 of geohydrologic data in the Navajo and Hopi Indian Reservations, Arizona, New Mexico, and Utah: Arizona State Land Department Water-Resources Report 12-A, 159 p.

Eychaner, J.H., 1983, Geohydrology and effects of water use in the Black Mesa area, Navajo and Hopi Indian Reservations, Arizona: U.S. Geological Survey Water-Supply Paper 2201, 26 p.

Fisk, G.G., Duet, N.R., Evans, D.W., Angeroth, C.E., Castillo, N.K., and Longsworth, S.A., 2004, Water-resources data for Arizona, water year 2003: U.S. Geological Survey WaterData Report AZ-03-1, 326 p.

Fisk, G.G., Duet, N.R., McGuire, E.H., Angeroth, C.E., Castillo, N.K., and Smith, C.F., 2005, Water-resources data for Arizona, water year 2004: U.S. Geological Survey WaterData Report AZ-04-1 p. 415

GeoTrans, Inc., 1987, A two-dimensional finite-difference flow model simulating the effects of withdrawals to the $\mathrm{N}$ aquifer, Black Mesa area, Arizona: Boulder, Colorado, GeoTrans, Inc., report prepared for Peabody Western Coal Company.
Harshbarger, J.W., Lewis, D.D., Skibitzke, H.E., Heckler, W.L., and Kister, L.R., 1966, Arizona water: U.S. Geological Survey Water-Supply Paper 1648, 85 p.

Hart, R.J., and Sottilare, J.P., 1988, Progress report on the ground-water, surface-water, and quality-of-water monitoring program, Black Mesa area, northeastern Arizona-1987-88: U.S. Geological Survey Open-File Report 88-467, 27 p.

Hart, R.J., and Sottilare, J.P., 1989, Progress report on the ground-water, surface-water, and quality-of-water monitoring program, Black Mesa area, northeastern Arizona-1988-89: U.S. Geological Survey Open-File Report 89-383, 33 p.

Hill, G.W., 1985, Progress report on Black Mesa monitoring program-1984: U.S. Geological Survey Open-File Report 85-483, 24 p.

Hill, G.W., and Sottilare, J.P., 1987, Progress report on the ground-water, surface-water, and quality-of-water monitoring program, Black Mesa area, northeastern Arizona-1987: U.S. Geological Survey Open-File Report 87-458, 29 p.

Hill, G.W., and Whetten, M.I., 1986, Progress report on Black Mesa monitoring program-1985-86: U.S. Geological Survey Open-File Report 86-414, 23 p.

HSIGeoTrans, Inc., 1993, Investigation of the N- and D-aquifer geochemistry and flow characteristics using major ion and isotopic chemistry, petrography, rock stress analyses, and dendrochronology in the Black Mesa area, Arizona: Boulder, Colorado, HSIGeoTrans, Inc., report prepared for Peabody Coal Company, 400 v.p.

HSIGeoTrans, Inc., and Waterstone Environmental Hydrology and Engineering, Inc., 1999, A three-dimensional flow model of the D and $\mathrm{N}$ aquifers, Black Mesa Basin, Arizona: Boulder, Colorado, HSIGeoTrans, Inc., and Waterstone Environmental Hydrology and Engineering, Inc., report prepared for Peabody Western Coal Company, 75 p.

Kister, L.R., and Hatchett, J.L., 1963, Selected chemical analyses of the ground water, part 2 of Geohydrologic data in the Navajo and Hopi Indian Reservations, Arizona, New Mexico, and Utah: Arizona State Land Department Water-Resources Report 12-B, 58 p.

Littin, G.R., 1992, Results of ground-water, surface-water, and water-quality monitoring, Black Mesa area, northeastern Arizona-1990-91: U.S. Geological Survey WaterResources Investigations Report 92-4045, 32 p.

Littin, G.R., 1993, Results of ground-water, surface-water, and water-quality monitoring, Black Mesa area, northeastern Arizona-1991-92: U.S. Geological Survey WaterResources Investigations Report 93-4111, 23 p. 
Littin, G.R., Baum, B.M., and Truini, Margot, 1999, Groundwater, surface-water, and water-chemistry data, Black Mesa area, northeastern Arizona-1999: U.S. Geological Survey Open-File Report 98-653, 27 p.

Littin, G.R., and Monroe, S.A., 1995a, Results of groundwater, surface-water, and water-quality monitoring, Black Mesa area, northeastern Arizona-1992-93: U.S. Geological Survey Water-Resources Investigations Report 95-4156, $37 \mathrm{p}$.

Littin, G.R., and Monroe, S.A., 1995b, Results of groundwater, surface-water, and water-chemistry monitoring, Black Mesa area, northeastern Arizona-1994: U.S. Geological Survey Water-Resources Investigations Report 95-4238, $25 \mathrm{p}$.

Littin, G.R., and Monroe, S.A., 1996, Ground-water, surfacewater, and water-chemistry data, Black Mesa area, northeastern Arizona-1995: U.S. Geological Survey Open-File Report 96-616, 22 p.

Littin, G.R., and Monroe, S.A., 1997, Ground-water, surfacewater, and water-chemistry data, Black Mesa area, northeastern Arizona-1996: U.S. Geological Survey Open-File Report 97-566, 27 p.

Lopes, T.J., and Hoffmann, J.P., 1997, Geochemical analyses of ground-water ages, recharge rates, and hydraulic conductivity of the N Aquifer, Black Mesa area, Arizona: U.S. Geological Survey Water-Resources Investigations Report 96-4190, $42 \mathrm{p}$.

McCormack, H.F., Fisk, G.G., Duet, N.R., Evans, D.W., and Castillo, N.K., 2002, Water-resources data for Arizona, water year 2001: U.S. Geological Survey Water-Data Report AZ-01-1, 399 p.

McCormack, H.F., Fisk, G.G., Duet, N.R., Evans, D.W., Roberts, W.P., and Castillo, N.K., 2003, Water-resources data for Arizona, water year 2002: U.S. Geological Survey Water-Data Report AZ-02-1, 337 p.

Smith, C.F., Anning, D.W., Duet, N.R., Fisk, G.G., McCormack, H.F., Pope, G.L., Rigas, P.D., and Wallace, B.L., 1995, Water-resources data for Arizona, water year 1994: U.S. Geological Survey Water-Data Report AZ-94-1, $320 \mathrm{p}$.

Smith, C.F., Boner, F.C., Davis, R.G., Duet, N.R., and Rigas, P.D., 1993, Water-resources data for Arizona, water year 1992: U.S. Geological Survey Water-Data Report AZ-92-1, $360 \mathrm{p}$.

Smith, C.F., Duet, N.R., Fisk, G.G., McCormack, H.F., Partin, C.K., Pope, G.L., Rigas, P.D., and Tadayon, Saeid, 1996, Water-resources data for Arizona, water year 1995: U.S. Geological Survey Water-Data Report AZ-95-1, $306 \mathrm{p}$.
Smith, C.F., Duet, N.R., Fisk, G.G., McCormack, H.F., Partin, C.K., Pope, G.L., and Rigas, P.D., 1997, Water-resources data for Arizona, water year 1996: U.S. Geological Survey Water-Data Report AZ-96-1, 328 p.

Smith, C.F., Rigas, P.D., Ham, L.K., Duet, N.R., and Anning, D.W., 1994, Water-resources data for Arizona, water year 1993: U.S. Geological Survey Water-Data Report AZ-93-1, $360 \mathrm{p}$.

Sottilare, J.P., 1992, Results of ground-water, surface-water, and water-quality monitoring, Black Mesa area, northeastern Arizona-1989-90: U.S. Geological Survey WaterResources Investigations Report 92-4008, 38 p.

Tadayon, Saeid, Duet, N.R., Fisk, G.G., McCormack, H.F., Partin, C.K., Pope, G.L., and Rigas, P.D., 1999, Waterresources data for Arizona, water year 1998: U.S. Geological Survey Water-Data Report AZ-98-1, 454 p.

Tadayon, Saeid, Duet, N.R., Fisk, G.G., McCormack, H.F., Partin, C.K., Pope, G.L., and Rigas, P.D., 2000, Waterresources data for Arizona, water year 1999: U.S. Geological Survey Water-Data Report AZ-99-1, 389 p.

Tadayon, Saeid, Duet, N.R., Fisk, G.G., McCormack, H.F., Partin, C.K., Pope, G.L., and Rigas, P.D., 2001, Waterresources data for Arizona, water year 2000: U.S. Geological Survey Water-Data Report AZ-00-1, 390 p.

Tadayon, Saeid, Duet, N.R., Fisk, G.G., McCormack, H.F., Pope, G.L., and Rigas, P.D., 1998, Water-resources data for Arizona, water year 1997: U.S. Geological Survey WaterData Report AZ-97-1, 416 p.

Thomas, B.E., 2002a, Ground-water, surface-water, and water-chemistry data, Black Mesa area, northeastern Arizona-2000-2001, and performance and sensitivity of the 1988 USGS numerical model of the N aquifer: U.S. Geological Survey Water-Resources Investigations Report 02-4211, $75 \mathrm{p}$.

Thomas, B.E., 2002b, Ground-water, surface-water, and water-chemistry data, Black Mesa area, northeastern Arizona-2001-02: U.S. Geological Survey Open-File Report 02-485, 43 p.

Thomas, B.E., and Truini, Margot, 2000, Ground-water, surface-water, and water-chemistry data, Black Mesa area, northeastern Arizona-1999: U.S. Geological Survey Open-File Report 00-453, 42 p.

Truini, Margot, Baum, B.M., Littin, G.R., and ShingoitewaHonanie, Gayl, 2000, Ground-water, surface-water, and water-chemistry data, Black Mesa area, northeastern Arizona-1998: U.S. Geological Survey Open-File Report 00-66, 37 p. 
Truini, Margot, and Longsworth, S.A., 2003, Hydrogeology of the D aquifer and movement and ages of ground water determined from geochemical and isotopic analyses, Black Mesa area, northeastern Arizona: U.S. Geological Survey Water-Resources Investigations Report 03-4189, 38 p.

Truini, Margot and Macy, J.P., 2005, Lithology and thickness of the Carmel Formation as related to leakage between the D and N aquifer, Black Mesa, Arizona: U.S. Geological Survey Scientific Investigation Report 2005-5187, 7 p.

Truini, Margot, and Macy, J.P., 2006, Ground-water, surfacewater, and water-chemistry data, Black Mesa area, northeastern Arizona-2004-05: U.S. Geological Survey OpenFile Report 2006-1058, 42 p.

Truini, Margot, and Macy, J.P., 2007, Ground-water, surfacewater, and water-chemistry data, Black Mesa area, northeastern Arizona-2005-06: U.S. Geological Survey OpenFile Report 2007-1041, 42 p.

Truini, Margot, Macy, J.P., and Porter T.J., 2005, Groundwater, surface-water, and water-chemistry data, Black Mesa area, northeastern Arizona-2003-04: U.S. Geological Survey Open-File Report 2005-1080, 44 p.

Truini, Margot, and Thomas, B.E., 2004, Ground-water, surface-water, and water-chemistry data, Black Mesa area, northeastern Arizona-2002-03: U.S. Geological Survey Open-File Report 03-503, 43 p.

U.S. Department of Agriculture, Natural Resources Conservation Service, 1999, Arizona annual precipitation: Fort Worth, Texas, USDA-NRCS National Cartography \& Geospatial Center, scale 1:1,300,000.

U.S. Environmental Protection Agency, 2002, Current drinking water standards, national primary and secondary drinking water regulations: Washington, D.C., U.S. Environmental Protection Agency [http://www.epa.gov/safewater/mcl. html 05:00P, last accessed January 31, 2006].

U.S. Geological Survey, 1963-64a, Surface-water records of Arizona: U.S. Geological Survey report, 191 p.

U.S. Geological Survey, 1963-64b, Ground-water records of Arizona: U.S. Geological Survey report, 80, p.

U.S. Geological Survey, 1965-74a, Water-resources data for Arizona-Part 1, surface-water records: U.S. Geological Survey Water-Resources Data Report, 212, p.
U.S. Geological Survey, 1965-74b, Water-resources data for Arizona-Part 2, ground-water records: U.S. Geological Survey Water-Resources Data Report, 89, p.

U.S. Geological Survey, 1976-83, Water-resources data for Arizona, water years 1975-81: U.S. Geological Survey Water-Resources Data Reports AZ-75-1 to AZ-81-1, $440 \mathrm{p}$.

U.S. Geological Survey, 1978, Progress report on Black Mesa monitoring program-1977: U.S. Geological Survey OpenFile Report 78-459, 38 p.

White, N.D., and Garrett, W.B., 1984, Water resources data for Arizona, water year 1982: U.S. Geological Survey Water-Data Report AZ-82-1, 440 p.

White, N.D., and Garrett, W.B., 1986, Water resources data for Arizona, water year 1983: U.S. Geological Survey Water-Data Report AZ-83-1, 387 p.

White, N.D., and Garrett, W.B., 1987, Water resources data for Arizona, water year 1984: U.S. Geological Survey Water-Data Report AZ-84-1, 381 p.

White, N.D., and Garrett, W.B., 1988, Water resources data for Arizona, water year 1985: U.S. Geological Survey Water-Data Report AZ-85-1, 343 p.

Wilson, R.P., and Garrett, W.B., 1988, Water resources data for Arizona, water year 1986: U.S. Geological Survey Water-Data Report AZ-86-1, 341 p.

Wilson, R.P., and Garrett, W.B., 1989, Water-resources data for Arizona, water year 1987: U.S. Geological Survey Water-Data Report AZ-87-1, 385 p.

Zhu, Chen, Waddell, R.K., Star, I., and Ostrander, M., 1998, Responses of ground water in the Black Mesa Basin, northeastern Arizona, to paleoclimatic changes during the late Pleistocene and Holocene: Geology, v. 26, no. 2, p. $127-130$.

Zhu, Chen, 2000, Estimate of recharge from radiocarbon dating of groundwater and numerical flow and transport modeling: Water Resources Research, v. 36, no. 9, p. 2607-2620. 
Figures 4 through 12 and Tables 5 through 14 
UNCONFINED AREA

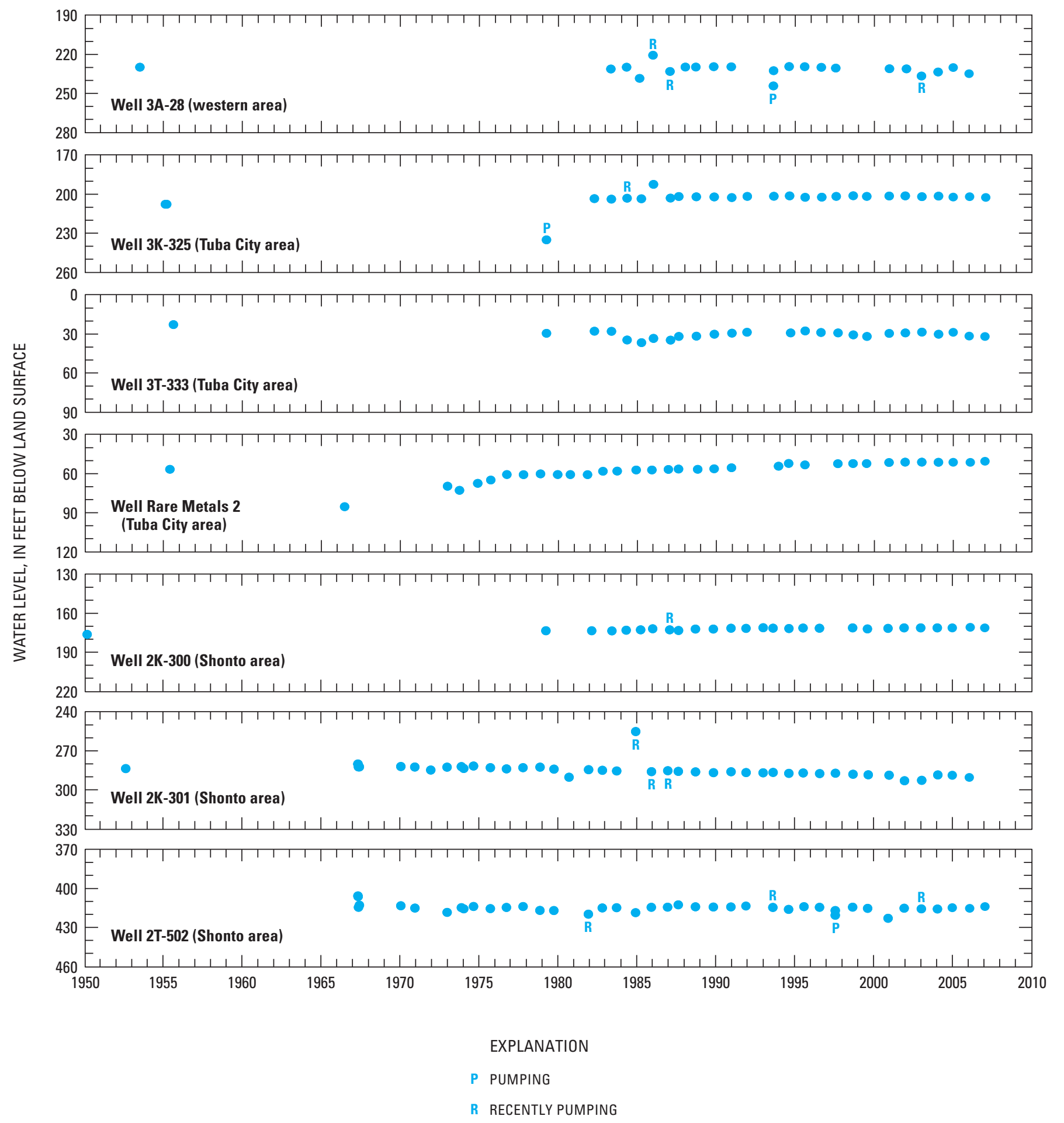

Figure 4. Observed water levels (1950-2007) in annual observation-well network, N aquifer, Black Mesa area, northeastern Arizona. 


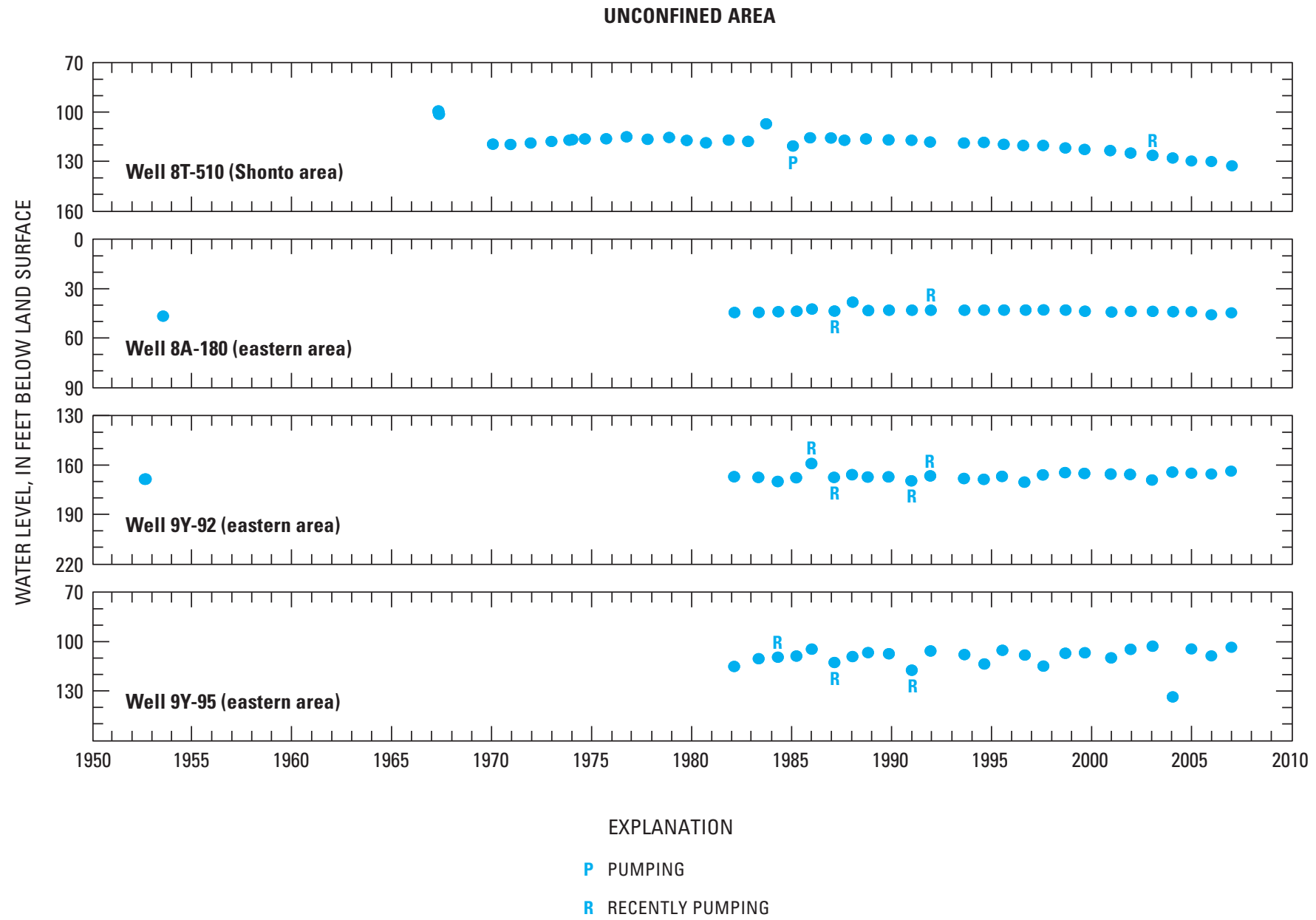

Figure 4. Observed water levels (1950-2007) in annual observation-well network, $\mathrm{N}$ aquifer, Black Mesa area, northeastern Arizona-Continued. 

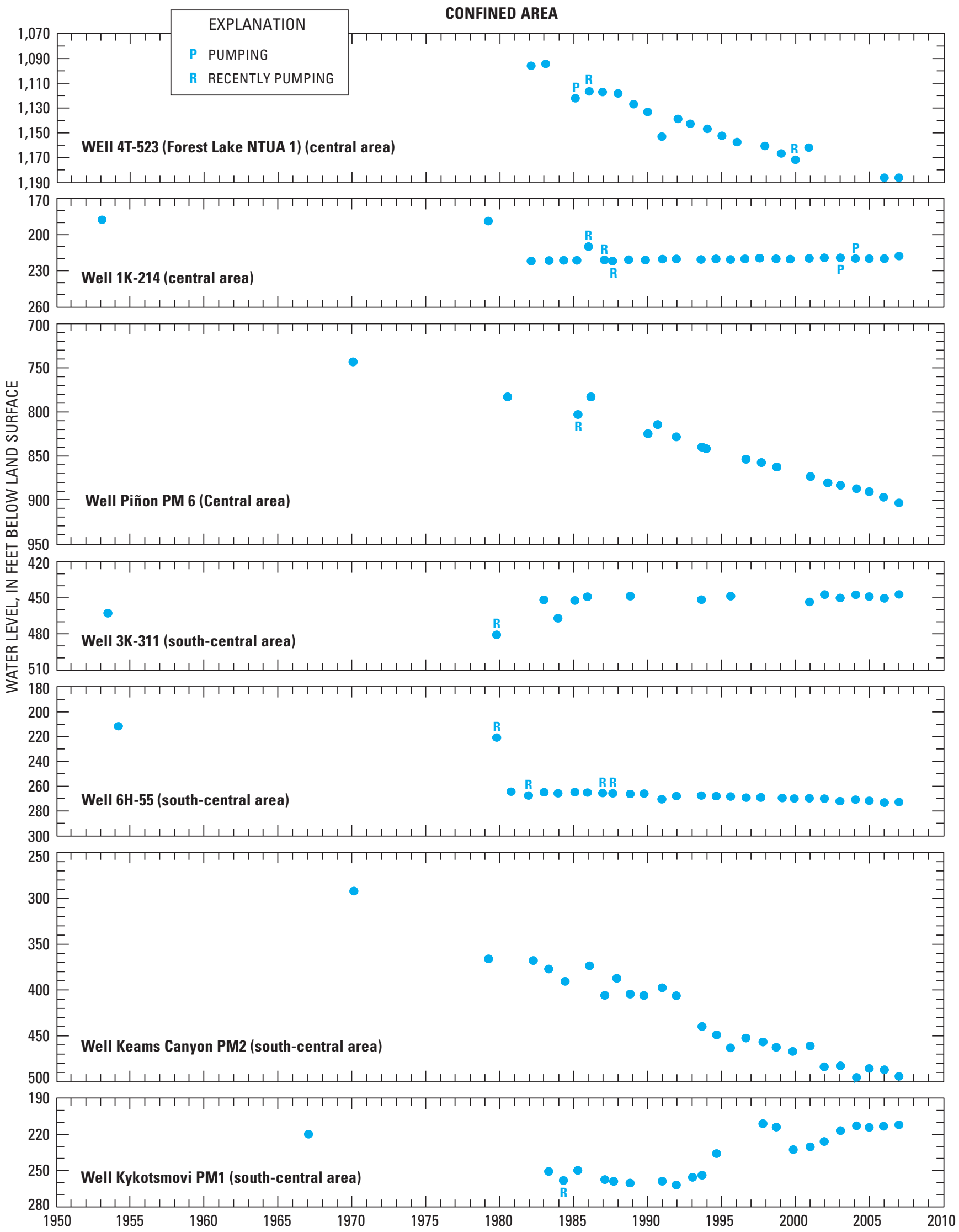

Figure 4. Observed water levels (1950-2007) in annual observation-well network, N aquifer, Black Mesa area, northeastern Arizona-Continued. 
CONFINED AREA

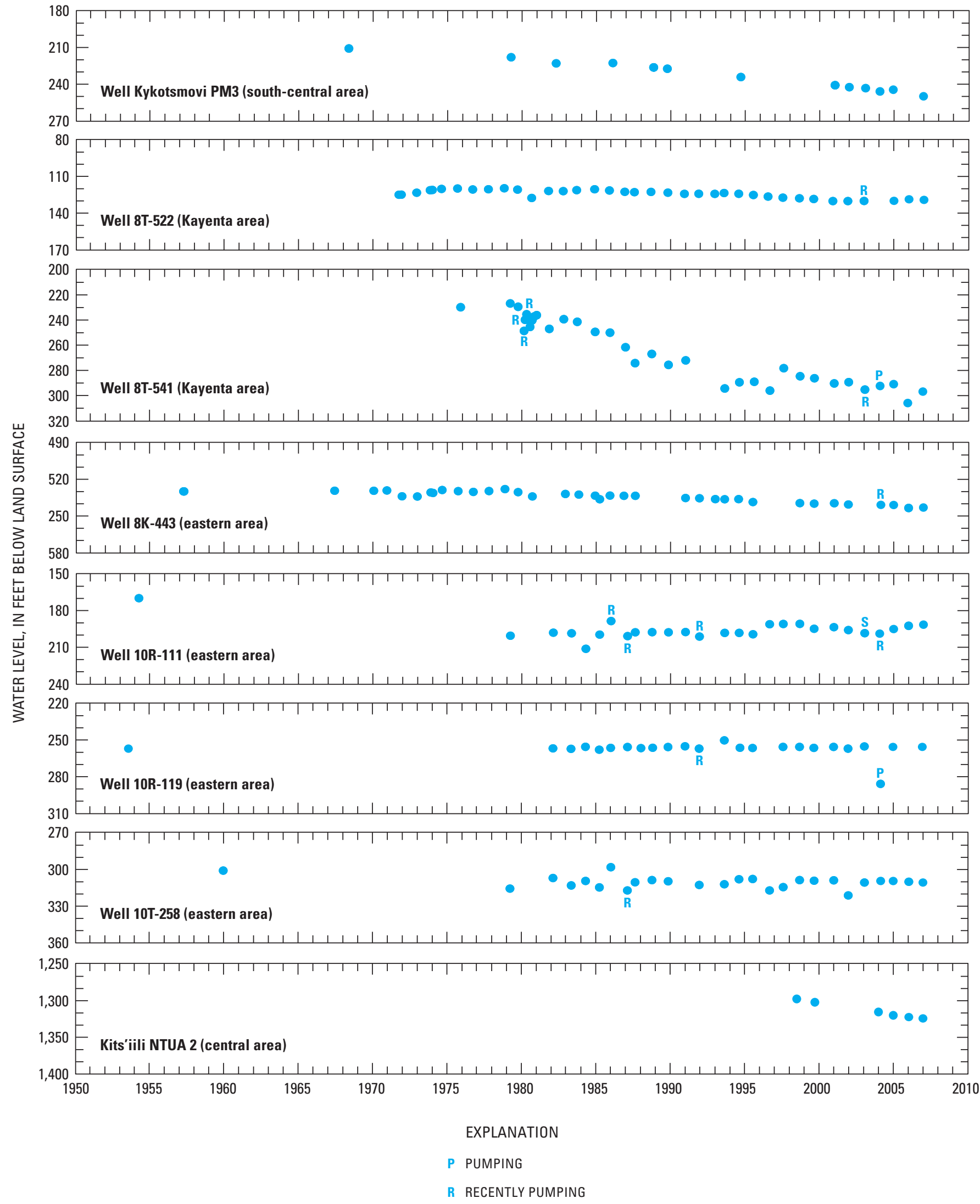

Figure 4. Observed water levels (1950-2007) in annual observation-well network, N aquifer, Black Mesa area, northeastern Arizona-Continued. 


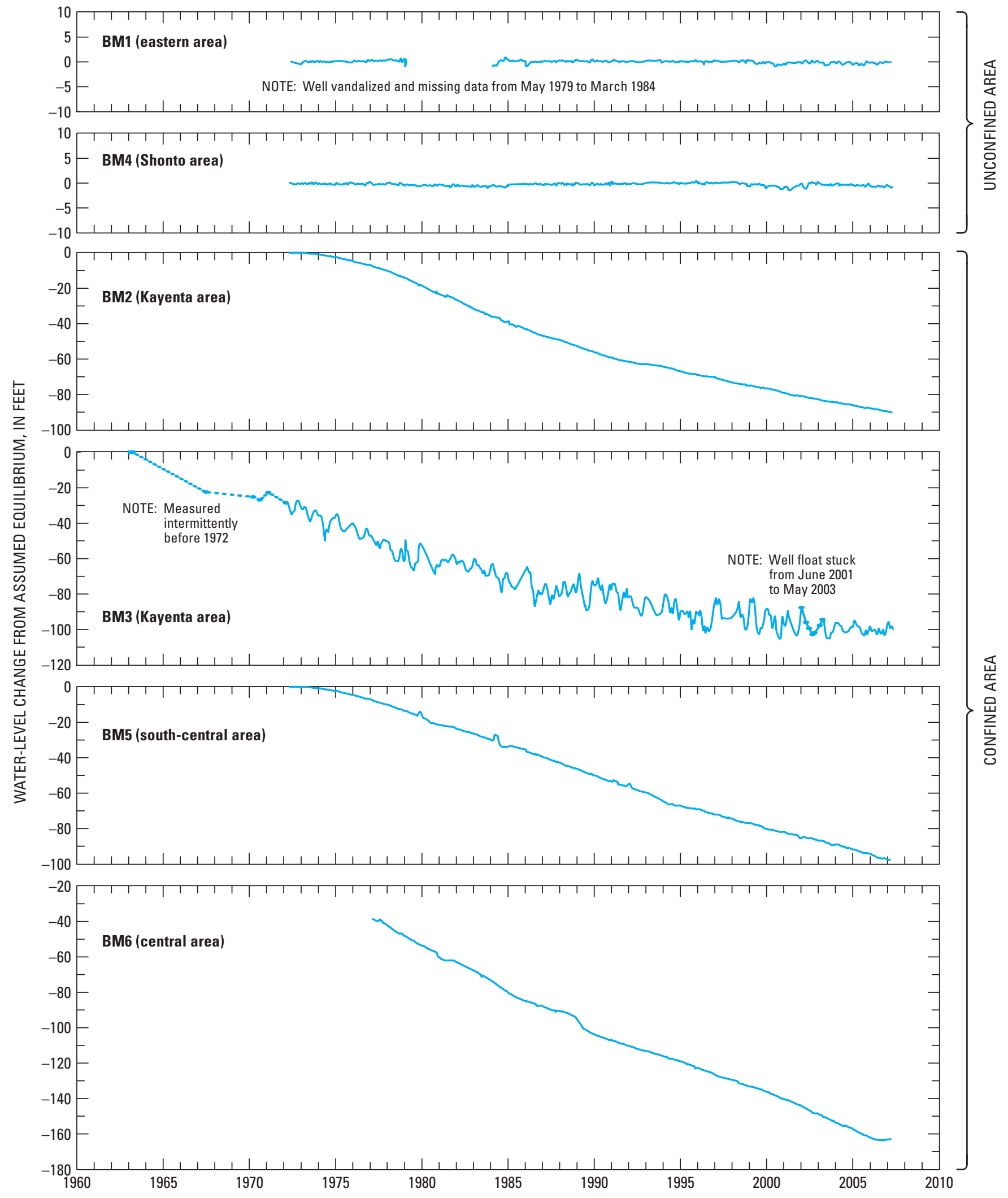

Figure 5. Observed water levels changes in continuous-record observation, wells, BM1-BM6, 1963-2007, N aquifer, Black Mesa area, northeastern Arizona. 


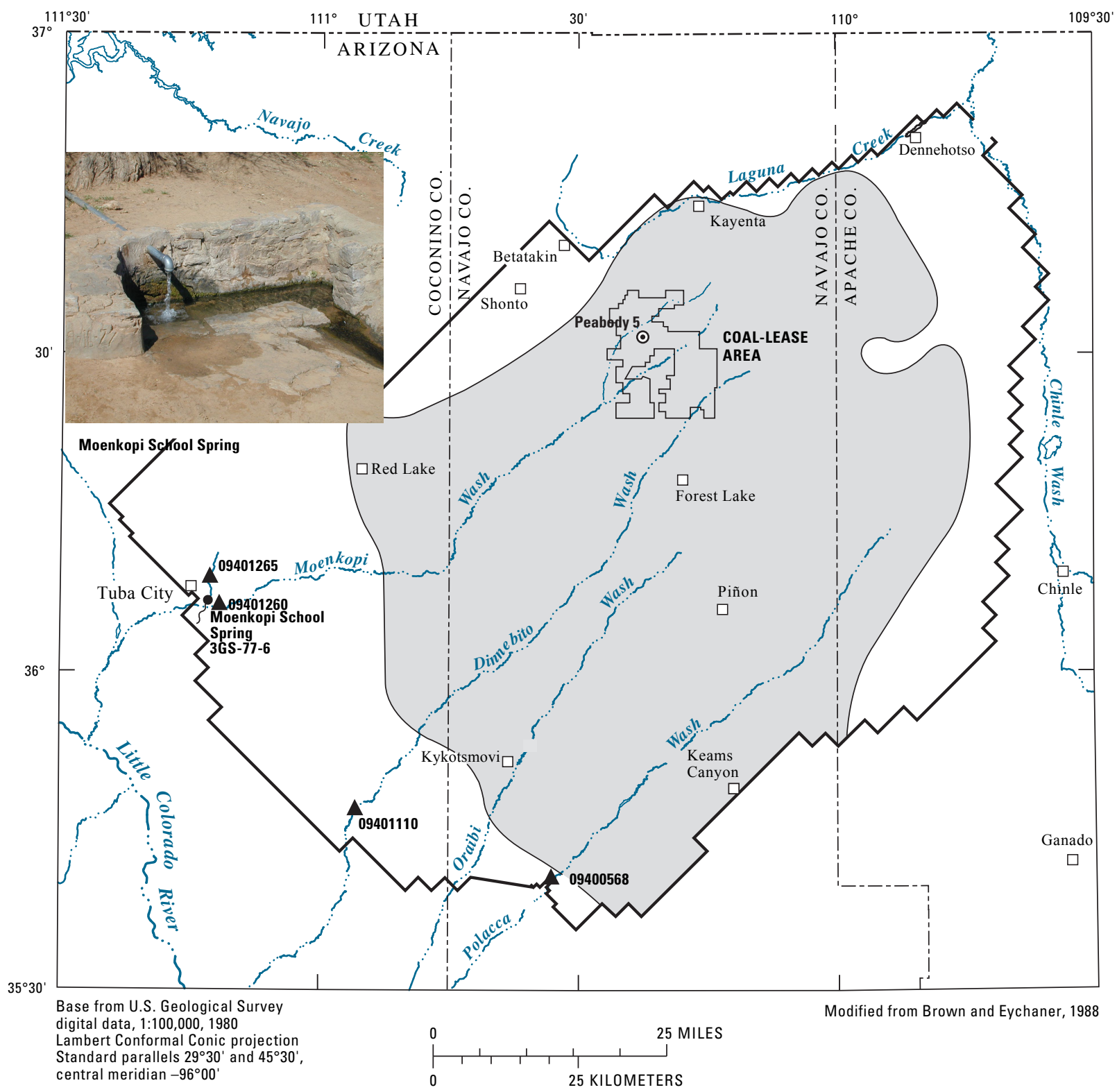

EXPLANATION

CONFINED AND UNCONFINED CONDITIONS IN THE N AQUIFER

○ INDUSTIAL WELL FROM WHICH WITHIN MODEL BOUNDARY

\section{Peabody 5}

WATER-CHEMISTRY SAMPLE

WAS COLLECTED-Peabody $\mathbf{5}$ is

Confined within the boundary of the mathematical model

a well number

Unconfined within the boundary of the mathematical model

APPROXIMATE BOUNDARY

BETWEEN CONFINED AND

UNCONFINED CONDITIONS -

From Brown and Eychaner (1988)

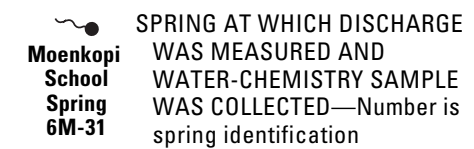
spring identification

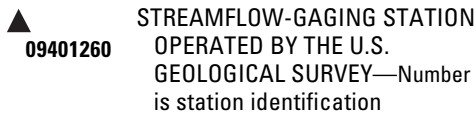

BOUNDARY OF MATHEMATICAL MODEL-

From Brown and Eychaner (1988)

Figure 6. Surface-water and water-chemistry data-collection sites, N aquifer, Black Mesa area, northeastern Arizona, 2006-07. 


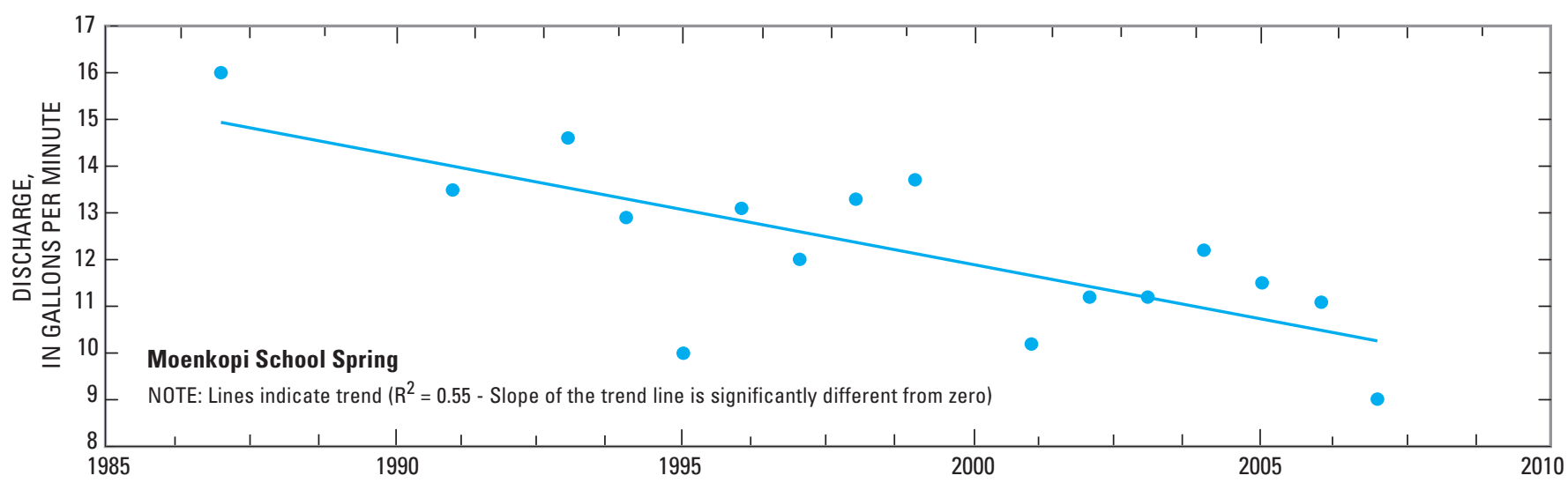

Figure 7. Discharge from Moenkopi School Spring, N aquifer, northeastern Black Mesa area, northeastern Arizona, 1987-2006. Data from earlier measurements at Moenkopi School Spring are not shown because different measuring locations were used. (Trend lines were generated by using the method of least squares).

A. Annual average discharge for calendar years 1977-2006.

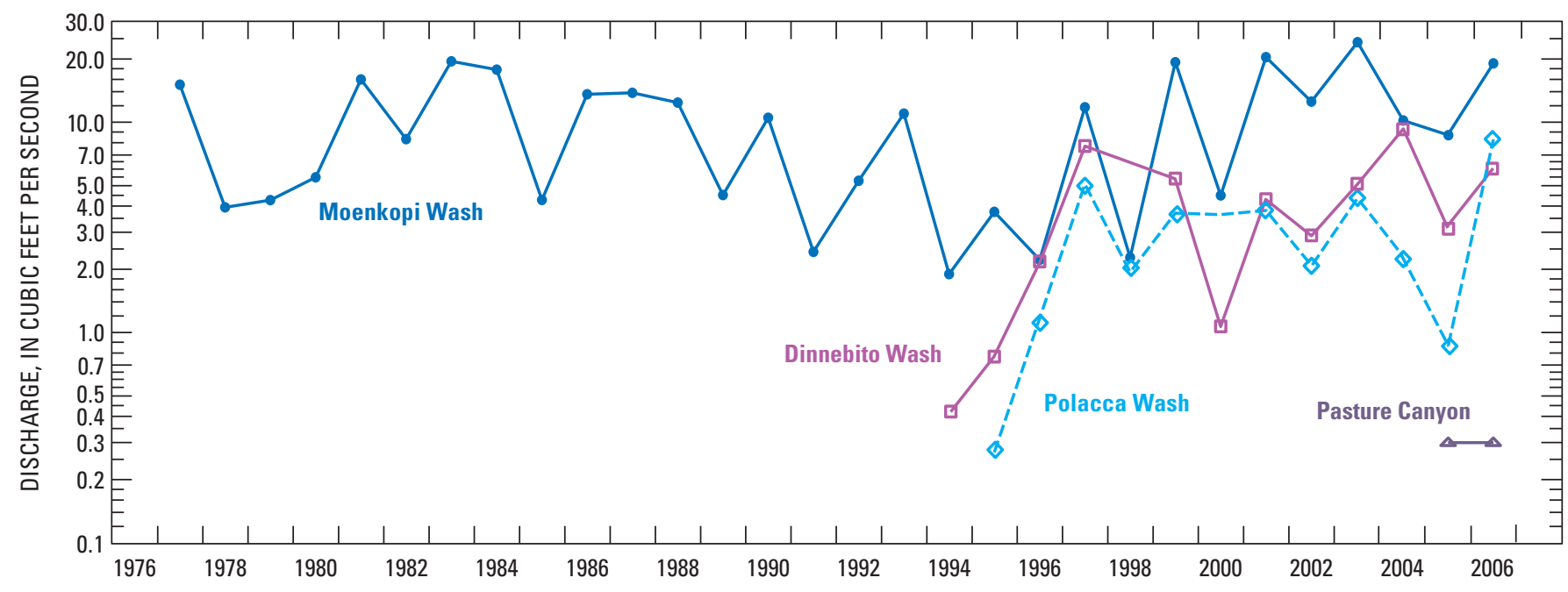

B. Annual precipitation at Betatakin, Arizona, calendar years 1976-2005 (National Weather Service).

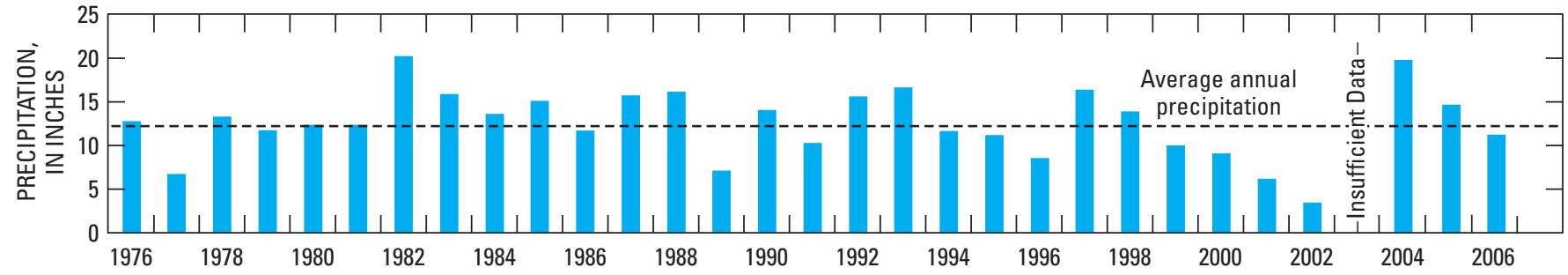

Figure 8. Streamflow characteristics at Moenkopi Wash at Moenkopi (09401260), Pasture Canyon Springs near Tuba City (09401265), Dinnebito Wash near Sand Spring (09401110), and Polacca Wash near Second Mesa (09400568), and annual precipitation at Betatakin, Arizona, Black Mesa area, northeastern Arizona. A, Annual average discharge for calendar years 1977-2006; $B$, Annual precipitation at Betatakin, Arizona, calendar years 1976-2006 (National Park Service, Betatakin National Monument, written commun., 2006). 
A, Daily median discharge for November, December, January, February, 1977-2006, for Moenkopi Wash at Moenkopi (09401260).

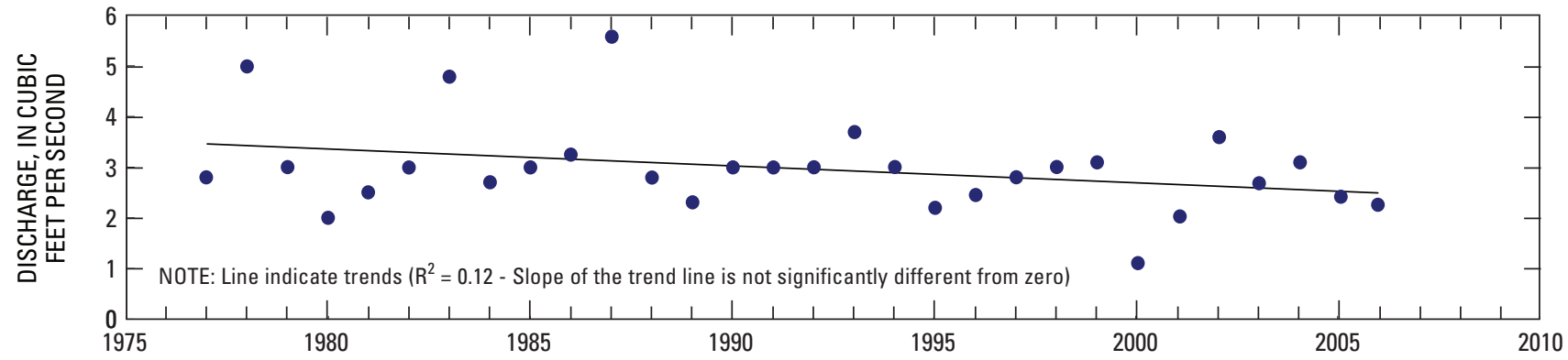

B, Daily median discharge for November, December, January, February, 1996-2006, Dinnebito Wash near Sand Spring (09401110).

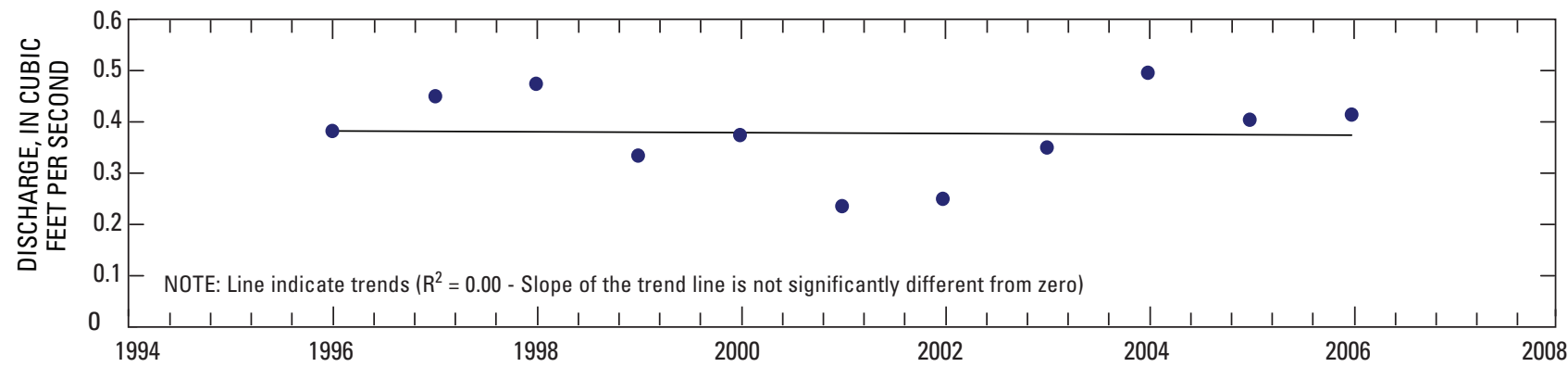

C, Daily median discharge for November, December, January, February, 1996-2006, Polacca Wash near Second Mesa (09400568).

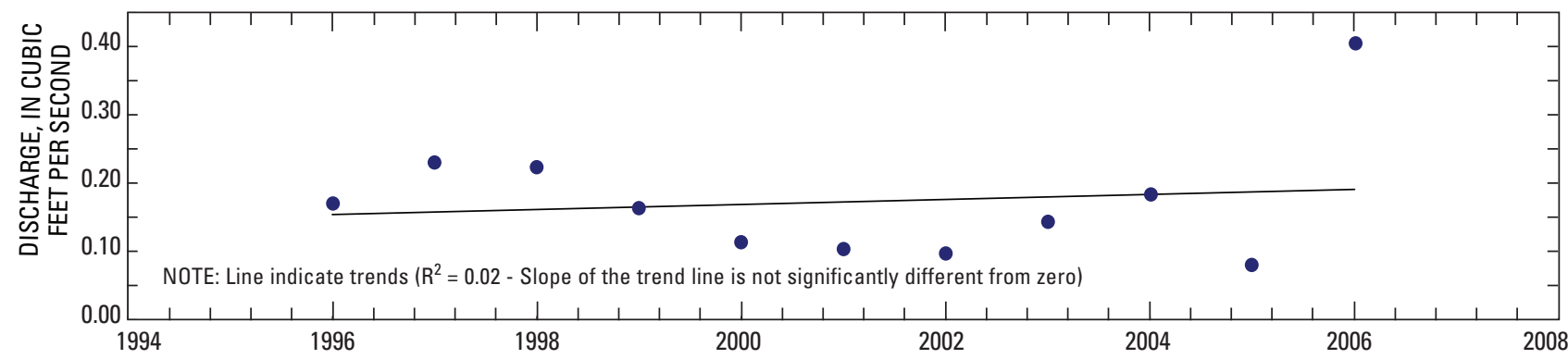

Figure 9. Median discharge for November, December, January, and February for water years 1977-2006 for Moenkopi Wash at (A) Moenkopi (09401260), (B) Dinnebito Wash near Sand Springs (09401110), and (C) Polacca Wash near Second Mesa (09400568), Black Mesa area, northeastern Arizona. Note: Trend lines were generated using the method of least squares. 


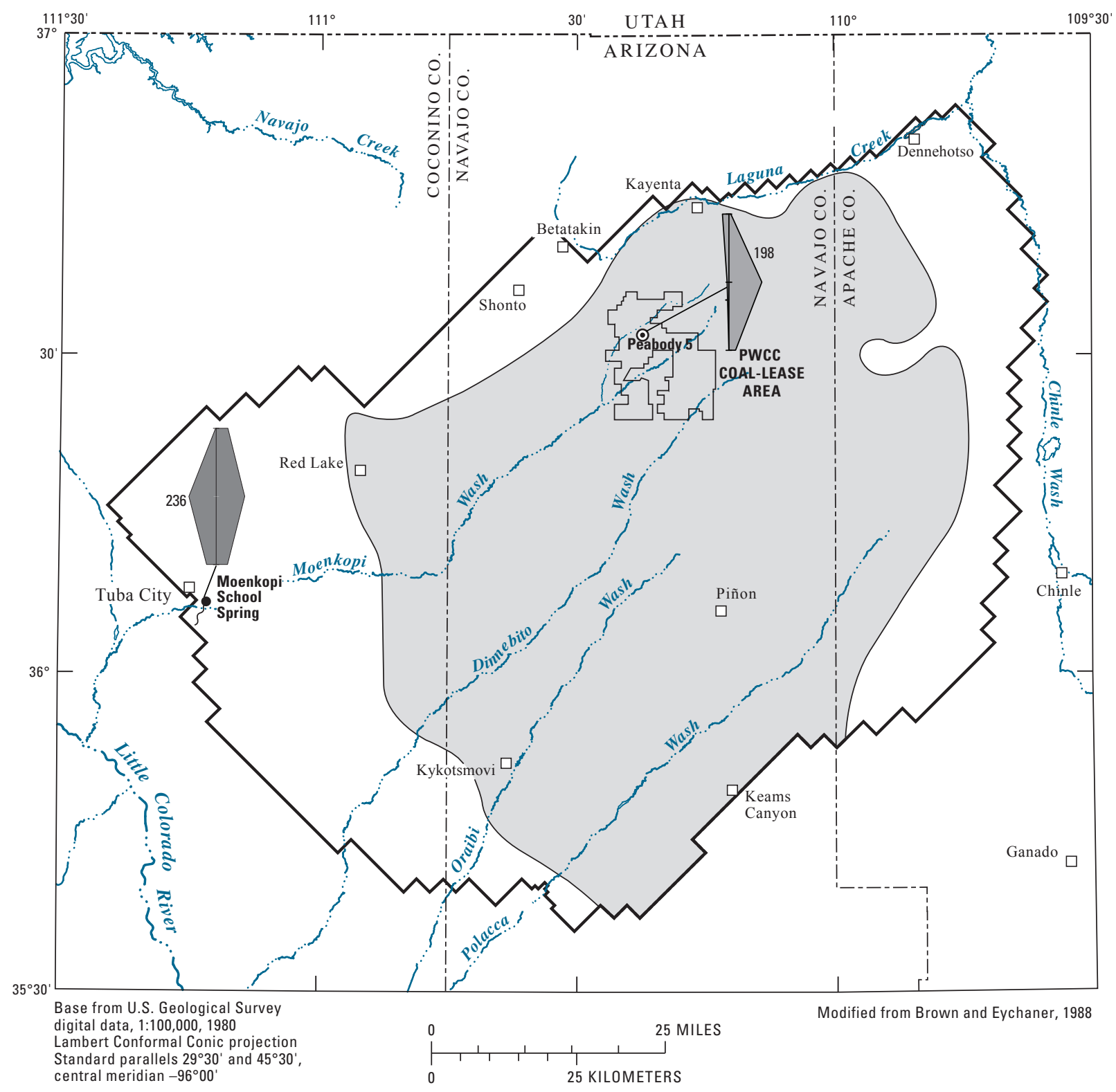

EXPLANATION

CONFINED AND UNCONFINED CONDITIONS IN THE N AQUIFER WITHIN MODEL BOUNDARY

\section{Confined within the boundary of the} mathematical model

Unconfined within the boundary of the mathematical model

APPROXIMATE BOUNDARY

BETWEEN CONFINED AND UNCONFINED CONDITIONS -

From Brown and Eychaner (1988) Moenkopi School WAS MEASURED AND WATERSpring CHEMISTRY SAMPLE WAS

$\odot$ INDUSTIAL WELL FROM WHICH
WATER-CHEMISTRY SAMPLE $\begin{array}{ll}\text { Peabody } 5 & \text { WATER-CHEMISTRY SAMPLE } \\ & \text { WAS COLLECTED-Peabody } 9 \text { is }\end{array}$ a well number

BOUNDARY OF MATHEMATICAL MODEL-From Brown and Eychaner (1988)

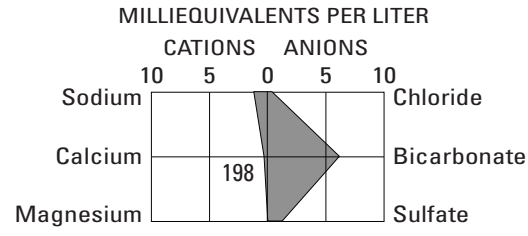

WATER-CHEMISTRY DIAGRAM-Shows major chemical constituents in milliequivalents per liter (meq/L). The diagram can be used to compare and characterize types of water. Number, 198 , is dissolved-solids concentration, in milligrams per liter.

Figure 10. Water chemistry and distribution of dissolved solids in the N aquifer, Black Mesa area, northeastern Arizona, 2007. 


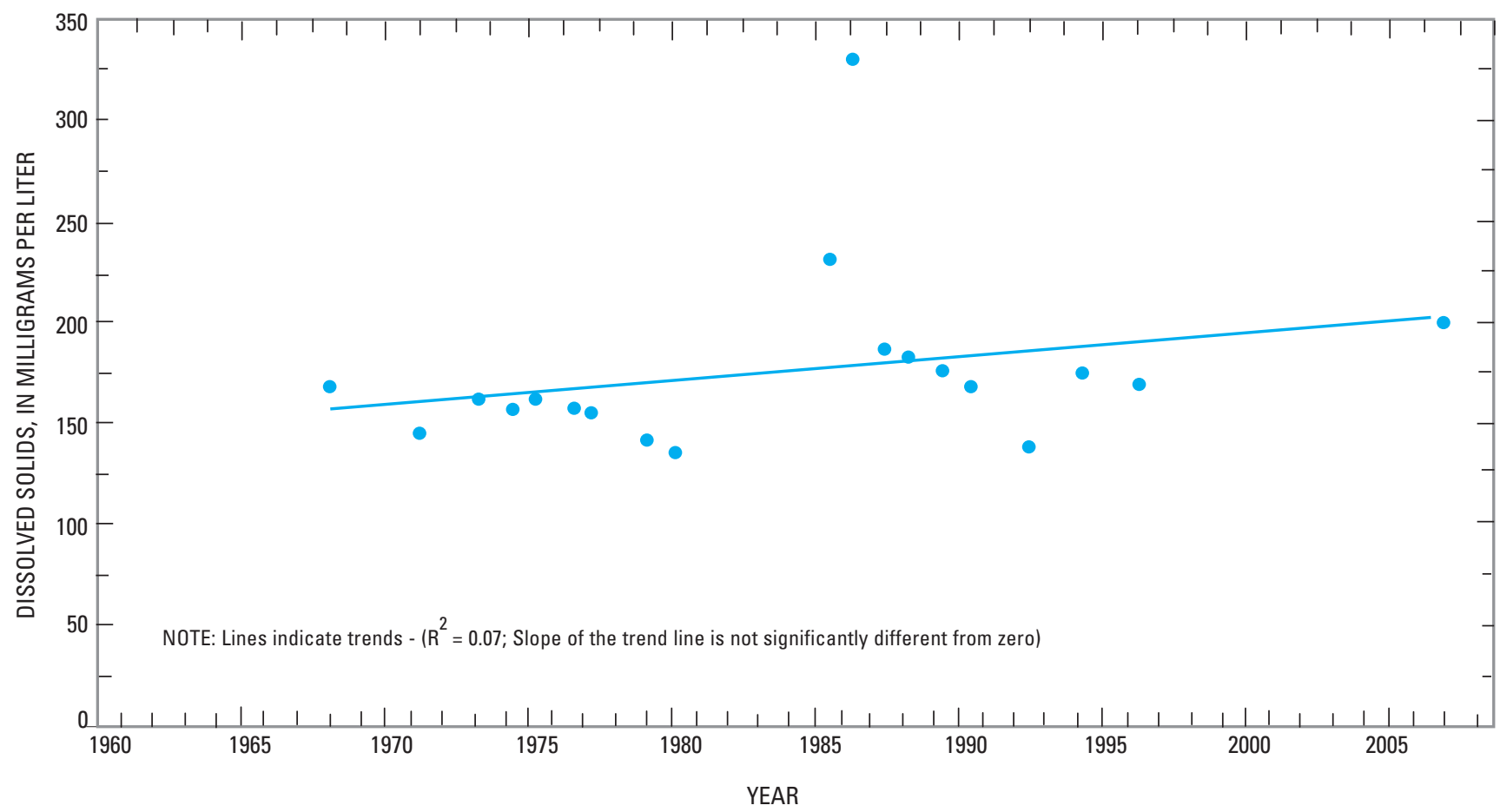

Figure 11. Dissolved-solids concentrations with linear trend line for water samples from industrial well Peabody $5, \mathrm{~N}$ aquifer, Black Mesa area, northeastern Arizona, 1980-2007. (Trend lines were generated by using the method of least squares). 

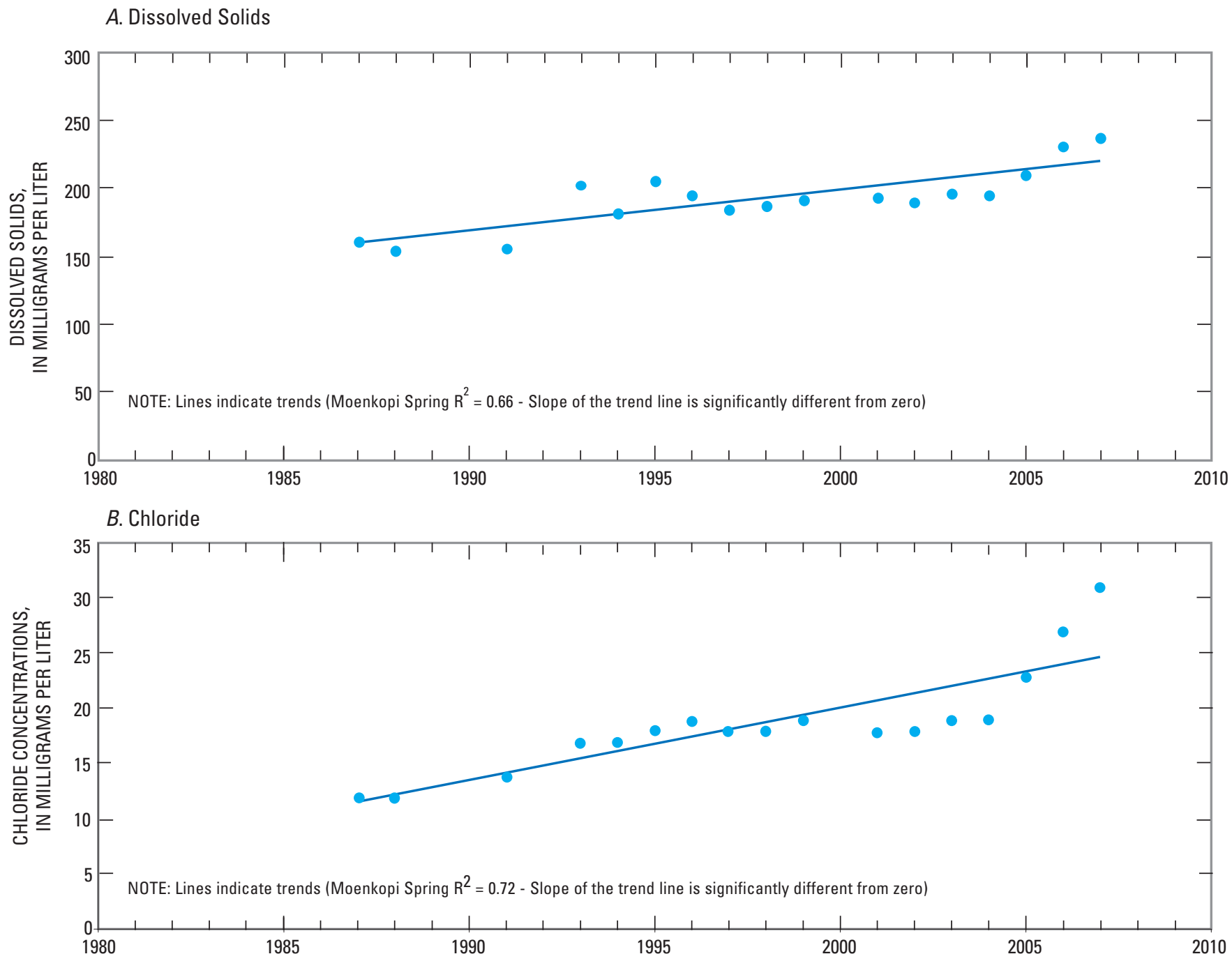

C. Sulfate

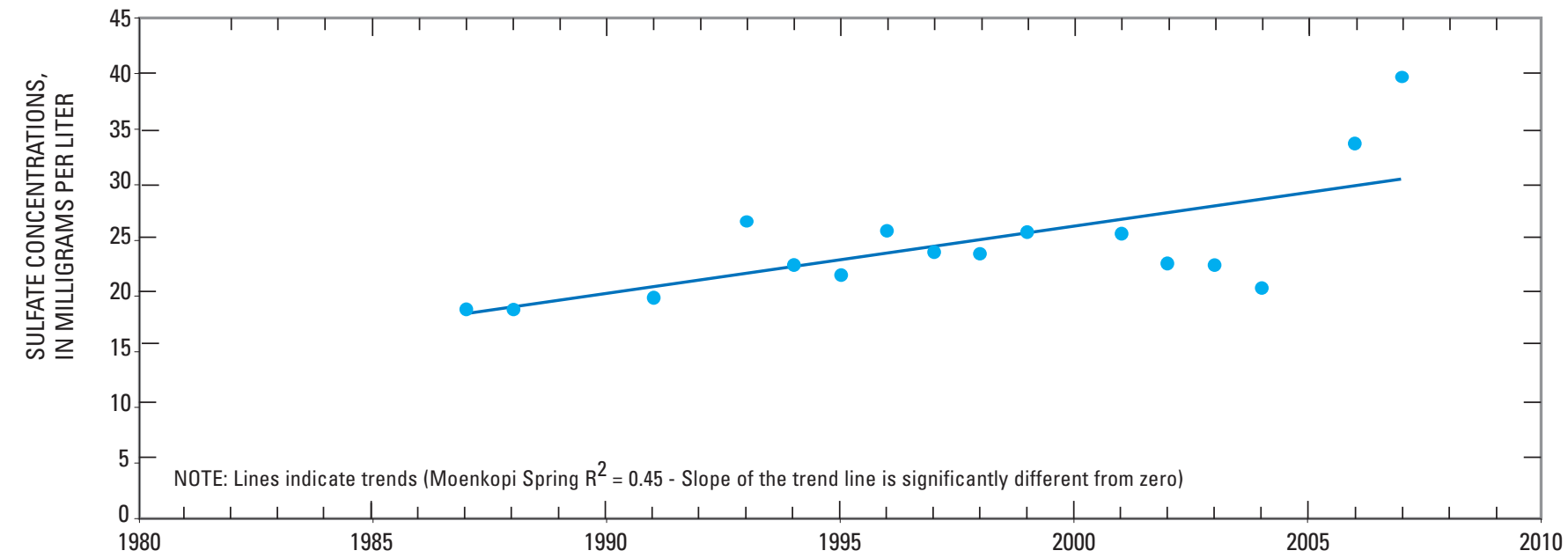

Figure 12. Concentrations of dissolved solids, chloride, and sulfate for water samples from Moenkopi School Spring, $\mathrm{N}$ aquifer Black Mesa area, northeastern Arizona, 1984-2007. A, Dissolved solids; $B$, Chloride; $C$, Sulfate. (Trend lines were generated by using the method of least squares). 
Table 5. Discharge measurements for Moenkopi School Spring, Black Mesa area, northeastern Arizona, 1952-2007.

[Measured discharges may not represent the total discharge from the spring]

\begin{tabular}{|c|c|c|c|}
\hline $\begin{array}{c}\text { Bureau of Indian } \\
\text { Affairs site } \\
\text { number }\end{array}$ & $\begin{array}{c}\text { Rock } \\
\text { formation(s) }\end{array}$ & $\begin{array}{c}\text { Date of measure- } \\
\text { ment }\end{array}$ & $\begin{array}{c}\text { Discharge, } \\
\text { in gallons } \\
\text { per minute }\end{array}$ \\
\hline \multicolumn{4}{|c|}{ Moenkopi School Spring ${ }^{1}$} \\
\hline \multirow[t]{18}{*}{$3 \mathrm{GS}-77-6$} & $\begin{array}{l}\text { Navajo } \\
\text { Sandstone }^{2}\end{array}$ & $05-16-52$ & 40.0 \\
\hline & & $04-22-87$ & ${ }^{3} 16.0$ \\
\hline & & $11-29-88$ & ${ }^{3} 43.6$ \\
\hline & & $02-21-91$ & ${ }^{3} 13.5$ \\
\hline & & 04-07-93 & ${ }^{3} 14.6$ \\
\hline & & $12-07-94$ & ${ }^{3} 12.9$ \\
\hline & & $12-04-95$ & ${ }^{3} 10.0$ \\
\hline & & $12-16-96$ & ${ }^{3} 13.1$ \\
\hline & & $12-17-97$ & ${ }^{3} 12.0$ \\
\hline & & $12-08-98$ & ${ }^{3} 13.3$ \\
\hline & & $12-13-99$ & ${ }^{3} 13.7$ \\
\hline & & $03-12-01$ & ${ }^{3} 10.2$ \\
\hline & & 06-19-02 & ${ }^{3} 11.2$ \\
\hline & & $05-01-03$ & ${ }^{3} 11.2$ \\
\hline & & 03-29-04 & ${ }^{3} 12.2$ \\
\hline & & 04-04-05 & ${ }^{3} 11.5$ \\
\hline & & $03-13-06$ & ${ }^{3} 11.1$ \\
\hline & & $05-31-07$ & ${ }^{3} 9.0$ \\
\hline
\end{tabular}

${ }^{1}$ Volumetric discharge measurement.

${ }^{2}$ Interfingering with the Kayenta Formation at this site.

${ }^{3}$ Discharge measured at water-quality sampling site and at a different point than the measurement in 1952. 
Table 6. Discharge data, Moenkopi Wash at Moenkopi, Arizona (09401260), calendar year 2006.

[Dashes indicate no data; e, estimated; units in cubic feet per second (cfs); cfsm, cubic feet per second per square mile]

\begin{tabular}{|c|c|c|c|c|c|c|c|c|c|c|c|c|}
\hline DAY & JAN & FEB & MAR & APR & MAY & JUN & JUL & AUG & SEP & ОСТ & NOV & DEC \\
\hline 1 & 0.36 & 0.42 & 0.41 & 0.37 & 0.34 & 0.28 & 0.28 & 0.28 & 0.27 & 0.23 & 0.30 & 0.32 \\
\hline 2 & 0.36 & 0.43 & 0.40 & 0.38 & 0.34 & 0.28 & 0.28 & 0.28 & 0.27 & 0.23 & 0.30 & 0.32 \\
\hline 4 & 0.34 & 0.41 & 0.41 & 0.36 & 0.34 & 0.28 & 0.28 & 0.31 & 0.27 & 0.23 & 0.30 & 0.32 \\
\hline 5 & 0.35 & 0.43 & 0.39 & 0.36 & 0.34 & 0.28 & 0.28 & 0.30 & 0.27 & 0.25 & 0.29 & 0.32 \\
\hline 7 & 0.36 & 0.43 & 0.38 & 0.38 & 0.34 & 0.27 & 0.28 & 0.27 & 0.27 & 0.30 & 0.30 & 0.32 \\
\hline 8 & 0.36 & 0.43 & 0.38 & 0.37 & 0.34 & 0.27 & 0.29 & 0.27 & 0.27 & 0.30 & 0.30 & 0.34 \\
\hline 9 & 0.36 & 0.43 & 0.38 & 0.36 & 0.34 & 0.27 & 0.32 & 0.27 & 0.27 & 0.30 & 0.30 & 0.34 \\
\hline 10 & 0.36 & 0.43 & 0.38 & 0.36 & 0.32 & 0.27 & 0.30 & 0.27 & 0.27 & 0.30 & 0.30 & 0.34 \\
\hline 14 & 0.37 & 0.43 & 0.41 & 0.36 & 0.30 & 0.26 & 0.29 & 0.28 & 0.31 & 0.29 & 0.30 & 0.34 \\
\hline 15 & 0.36 & 0.41 & 0.41 & $\mathrm{e} 0.35$ & 0.30 & 0.25 & 0.29 & 0.28 & $\mathrm{e} 0.28$ & 0.30 & 0.30 & 0.35 \\
\hline 16 & 0.36 & 0.42 & $\mathrm{e} 0.35$ & 0.41 & 0.30 & 0.25 & 0.29 & 0.28 & 0.26 & 0.30 & 0.30 & 0.36 \\
\hline 17 & 0.36 & 0.43 & $\mathrm{e} 0.35$ & 0.40 & 0.30 & 0.25 & 0.28 & 0.28 & 0.25 & 0.30 & 0.30 & 0.36 \\
\hline 18 & 0.36 & 0.43 & $\mathrm{e} 0.35$ & 0.38 & 0.30 & 0.25 & 0.27 & 0.28 & 0.25 & 0.30 & 0.30 & 0.36 \\
\hline 19 & 0.38 & 0.41 & $\mathrm{e} 0.35$ & 0.38 & 0.30 & 0.25 & 0.27 & 0.27 & 0.25 & 0.30 & 0.30 & 0.36 \\
\hline 20 & 0.38 & 0.42 & $\mathrm{e} 0.35$ & 0.38 & 0.30 & 0.25 & 0.28 & 0.27 & 0.25 & 0.30 & 0.30 & 0.36 \\
\hline 21 & 0.38 & 0.41 & $\mathrm{e} 0.35$ & 0.40 & 0.30 & 0.25 & 0.28 & 0.27 & 0.23 & 0.30 & 0.30 & 0.36 \\
\hline 28 & 0.38 & 0.40 & 0.37 & 0.34 & 0.28 & 0.28 & 0.28 & 0.27 & 0.23 & 0.30 & 0.32 & 0.36 \\
\hline 29 & 0.38 & - & 0.40 & 0.34 & 0.29 & 0.29 & 0.29 & 0.27 & 0.23 & 0.30 & 0.32 & 0.36 \\
\hline 30 & 0.40 & - & 0.38 & 0.34 & 0.29 & 0.29 & 0.30 & 0.27 & 0.23 & 0.30 & 0.32 & 0.36 \\
\hline 31 & 0.42 & - & 0.36 & - & 0.29 & - & 0.30 & 0.27 & - & 0.30 & - & 0.36 \\
\hline TOTAL & 11.43 & 11.59 & 12.18 & 10.59 & 9.61 & 7.94 & 8.84 & 8.56 & 7.69 & 8.90 & 9.16 & 10.73 \\
\hline MEAN & 0.37 & 0.41 & 0.39 & 0.35 & 0.31 & 0.26 & 0.29 & 0.28 & 0.26 & 0.29 & 0.31 & 0.35 \\
\hline MAX & 0.42 & 0.43 & 0.43 & 0.38 & 0.34 & 0.29 & 0.32 & 0.31 & 0.31 & 0.30 & 0.32 & 0.36 \\
\hline MIN & 0.34 & 0.38 & 0.36 & 0.33 & 0.28 & 0.25 & 0.27 & 0.27 & 0.23 & 0.23 & 0.29 & 0.32 \\
\hline MED & 0.36 & 0.42 & 0.39 & 0.35 & 0.30 & 0.26 & 0.28 & 0.27 & 0.26 & 0.30 & 0.30 & 0.36 \\
\hline AC-FT & 23 & 23 & 24 & 21 & 19 & 16 & 18 & 17 & 15 & 18 & 18 & 21 \\
\hline CFSM & 0.00 & 0.00 & 0.00 & 0.00 & 0.00 & 0.00 & $<0.01$ & $<0.04$ & $<0.01$ & $<0.07$ & 0.00 & 0.00 \\
\hline
\end{tabular}

$\begin{array}{cccccccc} & \text { Total } & \text { Mean } & \text { Max } & \text { Min. } & \text { Med. } & \text { Acre-ft } & \text { CFSM } \\ \text { Calendar year 2006 } & 117.22 & .32 & .43 & .23 & .32 & 23.23 & .0002\end{array}$ 
Table 7. Discharge data, Dinnebito Wash near Sand Springs, Arizona (09401110), calendar year 2006.

[Dashes indicate no data; e, estimated; units in cubic feet per second (cfs); cfsm, cubic feet per second per square mile]

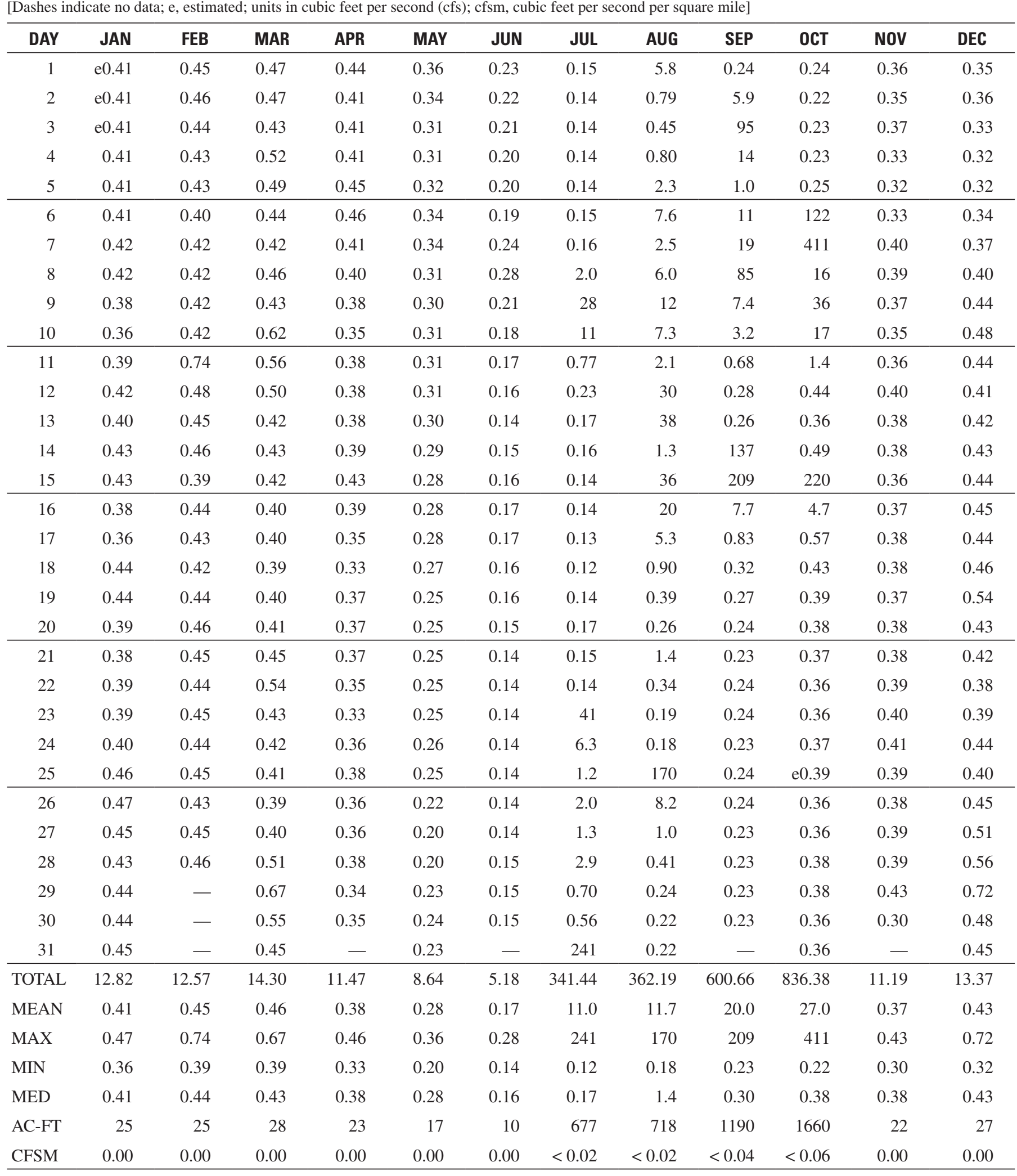


Table 8. Discharge data, Polacca Wash near Second Mesa, Arizona (09400568), calendar year 2006.

[Dashes indicate no data; e, estimated; units in cubic feet per second (cfs); cfsm, cubic feet per second per square mile]

\begin{tabular}{|c|c|c|c|c|c|c|c|c|c|c|c|c|}
\hline DAY & JAN & FEB & MAR & APR & MAY & JUN & JUL & AUG & SEP & ОСТ & NOV & DEC \\
\hline 2 & 0.10 & 0.09 & 0.09 & 0.11 & 0.26 & $<0.01$ & 0.00 & 2.9 & 0.28 & $\mathrm{e} 0.13$ & $\mathrm{e} 0.36$ & $\mathrm{e} 0.21$ \\
\hline 4 & 0.07 & 0.08 & 0.07 & 0.13 & 0.23 & $<0.01$ & 0.00 & 0.01 & 0.26 & $\mathrm{e} 0.13$ & $\mathrm{e} 0.34$ & $\mathrm{e} 0.21$ \\
\hline 5 & 0.07 & 0.08 & 0.07 & 0.17 & 0.21 & $<0.01$ & 0.00 & 30 & 0.24 & $\mathrm{e} 0.13$ & $\mathrm{e} 0.33$ & $\mathrm{e} 0.20$ \\
\hline 7 & 0.08 & 0.07 & 0.10 & 0.14 & 0.29 & $<0.01$ & 0.00 & 0.68 & $\mathrm{e} 0.23$ & 747 & $\mathrm{e} 0.33$ & 0.25 \\
\hline 8 & 0.08 & 0.08 & 0.08 & 0.13 & 0.25 & $<0.01$ & 0.00 & 0.21 & $\mathrm{e} 0.23$ & 73 & 0.74 & $\mathrm{e} 0.24$ \\
\hline 9 & 0.06 & 0.08 & 0.09 & 0.12 & 0.23 & $<0.01$ & 0.00 & 0.03 & $\mathrm{e} 0.23$ & 239 & 0.54 & 0.19 \\
\hline 10 & 0.02 & 0.07 & 0.18 & 0.13 & 0.24 & $<0.01$ & 0.00 & 6.3 & $\mathrm{e} 0.22$ & 63 & 0.51 & $\mathrm{e} 0.18$ \\
\hline 14 & 0.13 & 0.09 & 0.12 & 0.20 & 0.19 & 0.00 & 0.00 & e44 & $\mathrm{e} 0.18$ & 39 & 0.28 & $\mathrm{e} 0.25$ \\
\hline 15 & 0.13 & 0.14 & 0.11 & 0.18 & 0.19 & 0.00 & 0.00 & e83 & $\mathrm{e} 0.18$ & 34 & 0.31 & $\mathrm{e} 0.24$ \\
\hline 16 & 0.09 & 0.08 & 0.10 & 0.19 & 0.19 & 0.00 & 0.00 & e43 & $\mathrm{e} 0.17$ & e26 & 0.27 & $\mathrm{e} 0.24$ \\
\hline 17 & 0.04 & 0.11 & 0.10 & 0.20 & 0.19 & 0.00 & 0.00 & e20 & $\mathrm{e} 0.16$ & e19 & 0.23 & 0.22 \\
\hline 18 & 0.17 & 0.09 & 0.11 & 0.16 & 0.20 & 0.00 & 0.00 & e6.6 & $\mathrm{e} 0.16$ & 104 & 0.21 & $\mathrm{e} 0.23$ \\
\hline 19 & 0.12 & 0.09 & 0.09 & 0.18 & 0.18 & 0.00 & 0.00 & $\mathrm{e} 0.70$ & $\mathrm{e} 0.16$ & e18 & 0.19 & $\mathrm{e} 0.25$ \\
\hline 20 & 0.08 & 0.09 & 0.11 & 0.20 & 0.15 & 0.00 & 0.00 & $\mathrm{e} 0.50$ & $\mathrm{e} 0.16$ & e2.1 & 0.19 & $\mathrm{e} 0.27$ \\
\hline 21 & 0.03 & 0.09 & 0.11 & 0.20 & 0.11 & 0.00 & 0.00 & $\mathrm{e} 0.25$ & $\mathrm{e} 0.16$ & e1.1 & 0.17 & $\mathrm{e} 0.28$ \\
\hline 28 & 0.10 & 0.10 & 0.15 & 0.32 & 0.02 & 0.00 & 0.13 & e1.1 & $\mathrm{e} 0.14$ & $\mathrm{e} 0.40$ & 0.09 & $\mathrm{e} 0.34$ \\
\hline 29 & 0.11 & - & 0.18 & 0.28 & $<0.01$ & 0.00 & 0.30 & e9.9 & $\mathrm{e} 0.13$ & $\mathrm{e} 0.40$ & 0.09 & $\mathrm{e} 0.35$ \\
\hline 30 & 0.10 & - & 0.17 & 0.26 & $<0.01$ & 0.00 & 0.49 & 0.27 & $\mathrm{e} 0.13$ & $\mathrm{e} 0.40$ & 0.23 & $\mathrm{e} 0.37$ \\
\hline 31 & 0.09 & - & 0.14 & - & $<0.01$ & - & 761 & 0.23 & - & $\mathrm{e} 0.38$ & - & $\mathrm{e} 0.37$ \\
\hline TOTAL & 2.80 & 2.38 & 3.53 & 5.67 & 5.10 & 0.11 & 768.03 & 621.17 & 5.67 & 1629.05 & 8.32 & 8.24 \\
\hline MEAN & 0.09 & 0.09 & 0.11 & 0.19 & 0.16 & 0.00 & 24.8 & 20.0 & 0.19 & 52.5 & 0.28 & 0.27 \\
\hline MAX & 0.17 & 0.14 & 0.19 & 0.32 & 0.29 & 0.01 & 761 & 134 & 0.28 & 747 & 0.74 & 0.37 \\
\hline MIN & 0.02 & 0.05 & 0.07 & 0.11 & 0.01 & 0.00 & 0.00 & 0.01 & 0.13 & 0.13 & 0.08 & 0.18 \\
\hline MED & 0.09 & 0.09 & 0.10 & 0.18 & 0.19 & 0.00 & 0.00 & 2.9 & 0.17 & 1.1 & 0.28 & 0.25 \\
\hline AC-FT & 5.6 & 4.7 & 7.0 & 11 & 10 & 0.2 & 1520 & 1230 & 11 & 3230 & 17 & 16 \\
\hline CFSM & 0.00 & 0.00 & 0.00 & 0.00 & 0.00 & 0.00 & 0.03 & $<0.02$ & 0.00 & $<0.06$ & 0.00 & 0.00 \\
\hline
\end{tabular}

Calendar year 2006 Total Mean Max Min. Med. Acre-ft CFSM

$\begin{array}{lllllll}3060.07 & 8.2 & 761 & .01 & .18 & 6062.5 & .009\end{array}$ 
Table 9. Discharge data, Pasture Canyon Springs near Tuba City, Arizona (09401265), calendar year 2006.

[Dashes indicate no data; e, estimated; units in cubic feet per second (cfs)]

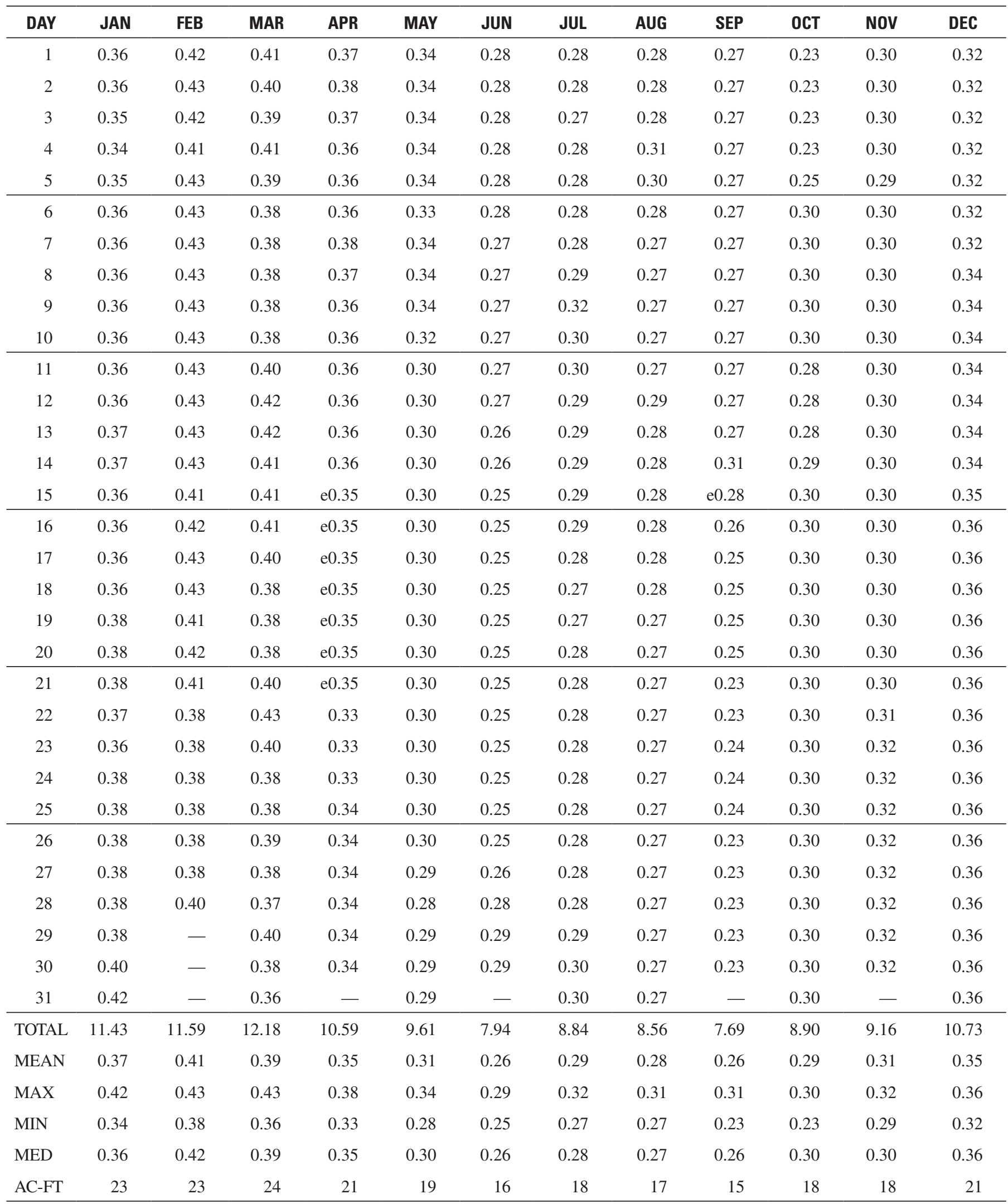

Calendar year 2006 Total Mean Max Min. Med. Acre-ft 
Table 10. Date that monitoring program data collection began and drainage areas for streamflow-gaging stations, Black Mesa area, northeastern Arizona.

[Dashes indicate area not determined]

\begin{tabular}{c|c|c|c}
\hline Station name & $\begin{array}{c}\text { Station } \\
\text { number }\end{array}$ & $\begin{array}{c}\text { Date data } \\
\text { collection } \\
\text { began }\end{array}$ & $\begin{array}{c}\text { Drainage } \\
\text { area, in } \\
\text { square miles }\end{array}$ \\
\hline $\begin{array}{c}\text { Moenkopi Wash } \\
\text { at Moenkopi }\end{array}$ & 9401260 & July 1976 & 1,629 \\
$\begin{array}{c}\text { Dinnebito Wash } \\
\text { near Sand Springs }\end{array}$ & 9401110 & June 1993 & 473 \\
$\begin{array}{c}\text { Polacca Wash } \\
\text { near Second Mesa }\end{array}$ & 9400568 & April 1994 & 905 \\
\begin{tabular}{c} 
Pasture Canyon Spring \\
\hline
\end{tabular} & 9401265 & August 2004 & - \\
\hline
\end{tabular}

Table 11. Physical properties and chemical analyses of water from industrial well Peabody 5 completed in the $N$ and $D$ aquifers, Black Mesa area, northeastern Arizona, 2007.

$\left[{ }^{\circ} \mathrm{C}\right.$, degrees Celsius; $\mu \mathrm{S} / \mathrm{cm}$, microsiemens per centimeter at $25^{\circ} \mathrm{C} ; \mathrm{mg} / \mathrm{L}$, milligrams per liter; $\mu \mathrm{g} / \mathrm{L}$, micrograms per liter; $<$, less than]

\begin{tabular}{|c|c|}
\hline Common well name & Peabody 5 \\
\hline U.S. Geological Survey identification number & 362901110234101 \\
\hline Date of samples & 04-19-2007 \\
\hline Temperature, field (degrees Celsius) & 30.9 \\
\hline Specific conductance, field $(\mu \mathrm{S} / \mathrm{cm})$ & 331 \\
\hline $\mathrm{pH}$, field, units & 9.5 \\
\hline Alkalinity, field, dissolved (mg/L as $\mathrm{CaCO}_{3}$ ) & 121.1 \\
\hline Nitrogen, $\mathrm{NO}_{2}+\mathrm{NO}_{3}$, dissolved $(\mathrm{mg} / \mathrm{L}$ as $\mathrm{N})$ & 1 \\
\hline Ortho-phosphate, dissolved (mg/L as P) & 0.035 \\
\hline Calcium, dissolved (mg/L as Ca) & 2.62 \\
\hline Magnesium dissolved (mg/L as Mg) & 0.032 \\
\hline Potassium, dissolved (mg/L as $\mathrm{K})$ & 0.7 \\
\hline Sodium, dissolved (mg/L as $\mathrm{Na}$ ) & 67.4 \\
\hline Chloride, dissolved, in $\mathrm{mg} / \mathrm{L}$ as $\mathrm{Cl}$ & 4.97 \\
\hline Fluoride, dissolved, in $\mathrm{mg} / \mathrm{L}$ as $\mathrm{F}$ & 0.26 \\
\hline Silica, dissolved, in $\mathrm{mg} / \mathrm{L}$ as $\mathrm{SiO} 2$ & 21 \\
\hline Sulfate, dissolved, in $\mathrm{mg} / \mathrm{L}$ as $\mathrm{SO} 4$ & 23.4 \\
\hline Arsenic, dissolved, in $\mu \mathrm{g} / \mathrm{L}$ as As & 2.7 \\
\hline Boron, dissolved, in $\mu \mathrm{g} / \mathrm{L}$ as B & 36 \\
\hline Iron, dissolved, in $\mu \mathrm{g} / \mathrm{L}$ as $\mathrm{Fe}$ & $<6$ \\
\hline Dissolved solids residue at $180^{\circ} \mathrm{C}$, in $\mathrm{mg} / \mathrm{L}$ & 198 \\
\hline
\end{tabular}

Table 12. Specific conductance and concentrations of selected chemical constituents in water from industrial well Peabody 5 completed in the $\mathrm{N}$ and $\mathrm{D}$ aquifers, Black Mesa area, northeastern Arizona, 1974-2007.

$\left[\mu \mathrm{S} / \mathrm{cm}\right.$, microsiemens per centimeter at $25^{\circ} \mathrm{C} ;{ }^{\circ} \mathrm{C}$, degrees Celsius; $\mathrm{mg} / \mathrm{L}$, milligram per liter; <, less than. Dashes indicate no data]

\begin{tabular}{c|c|c|c|c}
\hline Year & $\begin{array}{c}\text { Specific } \\
\text { conduc- } \\
\text { tance, field, } \\
\text { in } \mathbf{H S / c m}\end{array}$ & $\begin{array}{c}\text { Dissolved } \\
\text { solids, resi- } \\
\text { due at 180 C, } \\
\text { in mg/L }\end{array}$ & $\begin{array}{c}\text { Chloride, } \\
\text { dissolved, } \\
\text { in } \mathbf{~ m g / L ~} \\
\text { as Cl }\end{array}$ & $\begin{array}{c}\text { Sulfate } \\
\text { dissolved, in } \\
\text { mg/L as SO }\end{array}$ \\
\hline \multicolumn{5}{c}{ Peabody 5 } \\
\hline 1968 & 224 & 168 & 3.5 & 16.0 \\
1971 & 226 & 145 & 2.1 & 12.0 \\
1973 & - & 162 & - & - \\
1974 & 210 & 157 & 2.7 & 12.0 \\
1975 & 240 & 162 & 4.0 & 18.0 \\
1977 & 220 & 158 & 3.0 & 13.0 \\
1977 & 220 & 155 & 3.0 & 12.0 \\
1979 & 220 & 142 & 2.9 & 15.0 \\
1980 & 210 & 135 & 2.9 & 9.5 \\
1986 & 398 & 231 & 8.0 & 28.0 \\
1986 & 602 & 330 & 12.0 & 62.0 \\
1987 & 270 & - & 4.6 & 21.0 \\
1988 & 270 & 187 & 5.1 & 22.0 \\
1988 & 263 & 183 & 4.1 & 26.0 \\
1990 & 262 & 176 & 4.1 & 18.0 \\
1991 & 260 & 168 & 3.0 & 18.0 \\
1993 & 257 & 138 & 2.3 & 4.8 \\
1994 & 279 & 175 & 4.7 & 20.0 \\
1996 & - & - & 4.1 & 18.0 \\
1996 & 274 & 169 & 4.1 & 19.0 \\
2007 & 331 & 198 & 5.0 & 23.4 \\
\hline
\end{tabular}


Table 13. Physical properties and chemical analyses of $\mathrm{N}$-aquifer water samples from Moenkopi School Spring,Black Mesa area, northeastern Arizona, 2007.

$\left[{ }^{\circ} \mathrm{C}\right.$, degree Celsius; $\mu \mathrm{S} / \mathrm{cm}$, microsiemens per centimeter at $25^{\circ} \mathrm{C} ; \mathrm{mg} / \mathrm{L}$, milligrams per liter; $\mu \mathrm{g} / \mathrm{L}$, micrograms per liter; $<$, less than]

\begin{tabular}{|c|c|}
\hline Common well name & Peabody 5 \\
\hline U.S. Geological Survey identification number & 360632111131101 \\
\hline Bureau of Indian Affairs site number & $3 \mathrm{GS}-77-6$ \\
\hline Common spring name & Moenkopi School Spring \\
\hline Date of samples & $05-13-2007$ \\
\hline Temperature, field (degrees Celsius) & 17.9 \\
\hline Specific conductance, field $(\mu \mathrm{S} / \mathrm{cm})$ & 405.3 \\
\hline $\mathrm{pH}$, field, units & 7.2 \\
\hline Alkalinity, field, dissolved (mg/L as $\mathrm{CaCO}_{3}$ ) & 105.1 \\
\hline Nitrogen, $\mathrm{NO}_{2}+\mathrm{NO}_{3}$, dissolved $(\mathrm{mg} / \mathrm{L}$ as $\mathrm{N})$ & 2.7 \\
\hline Ortho-phosphate, dissolved (mg/L as P) & 0.019 \\
\hline Calcium, dissolved (mg/L as $\mathrm{Ca})$ & 40.2 \\
\hline Magnesium dissolved (mg/L as $\mathrm{Mg}$ ) & 8.61 \\
\hline Potassium, dissolved (mg/L as $\mathrm{K}$ ) & 1.49 \\
\hline Sodium, dissolved (mg/L as $\mathrm{Na}$ ) & 31.8 \\
\hline Chloride, dissolved, in $\mathrm{mg} / \mathrm{L}$ as $\mathrm{Cl}$ & 30.6 \\
\hline Fluoride, dissolved, in $\mathrm{mg} / \mathrm{L}$ as $\mathrm{F}$ & 0.18 \\
\hline Silica, dissolved, in $\mathrm{mg} / \mathrm{L}$ as $\mathrm{SiO} 2$ & 13.2 \\
\hline Sulfate, dissolved, in $\mathrm{mg} / \mathrm{L}$ as $\mathrm{SO} 4$ & 39.9 \\
\hline Arsenic, dissolved, in $\mu \mathrm{g} / \mathrm{L}$ as As & 2.5 \\
\hline Boron, dissolved, in $\mu \mathrm{g} / \mathrm{L}$ as $\mathrm{B}$ & 41 \\
\hline Iron, dissolved, in $\mu \mathrm{g} / \mathrm{L}$ as $\mathrm{Fe}$ & $<6$ \\
\hline Dissolved solids residue at $180^{\circ} \mathrm{C}$, in $\mathrm{mg} / \mathrm{L}$ & 238 \\
\hline
\end{tabular}

Table 14. Specific conductance and concentrations of selected chemical constituents in $\mathrm{N}$-aquifer water samples from Moenkopi School Spring, Black Mesa area, northeastern Arizona, 1948-2007. $\left[\mu \mathrm{S} / \mathrm{cm}\right.$, microsiemens per centimeter at $25^{\circ} \mathrm{C} ; \mathrm{mg} / \mathrm{L}$, milligrams per liter; ${ }^{\circ} \mathrm{C}$, degrees Celsius. Dashes indicate no data]

\begin{tabular}{l|c|c|c|c}
\hline Year & $\begin{array}{c}\text { Specific } \\
\text { conductance, } \\
\text { field, in } \mathbf{H} / \mathbf{c m}\end{array}$ & $\begin{array}{c}\text { Dissolved solids, } \\
\text { residue at 180 } \mathbf{C}, \\
\text { in mg/L }\end{array}$ & $\begin{array}{c}\text { Chloride, } \\
\text { dissolved, } \\
\text { in } \mathbf{~ m g / L ~ a s ~ C l ~}\end{array}$ & $\begin{array}{c}\text { Sulfate, } \\
\text { dissolved, } \\
\text { in } \mathbf{m g / L} \text { as } \\
\mathbf{S O}_{4}\end{array}$ \\
\hline \multicolumn{5}{c}{ Moenkopi School Spring } \\
\hline 1952 & 222 & - & 6 & - \\
1987 & 270 & 161 & 12 & 19 \\
1988 & 270 & 155 & 12 & 19 \\
1991 & 297 & 157 & 14 & 20 \\
1993 & 313 & 204 & 17 & 27 \\
1994 & 305 & 182 & 17 & 23 \\
1995 & 314 & 206 & 18 & 22 \\
1996 & 332 & 196 & 19 & 26 \\
1997 & 1305 & 185 & 18 & 24 \\
1998 & 296 & 188 & 18 & 24 \\
1999 & 305 & 192 & 19 & 26 \\
2001 & 313 & 194 & 18 & 26 \\
2002 & 316 & 191 & 18 & 23 \\
2003 & 344 & 197 & 19 & 23 \\
2004 & 349 & 196 & 19 & 21 \\
2005 & 349 & 212 & 23 & 30 \\
2006 & 387 & 232 & 27 & 34 \\
2007 & 405 & 238 & 31 & 40 \\
\hline
\end{tabular}

${ }^{1}$ Value is different in Black Mesa monitoring reports before 2000. Earlier reports showed values determined by laboratory analysis. 
